\title{
IDENTIFICATION AND CHARACTERIZATION OF HYDROGEOLOGIC UNITS AT THE NEVADA TEST SITE USING GEOPHYSICAL LOGS: \\ EXAMPLES FROM THE \\ UNDERGROUND TEST AREA SUB-PROJECT
}

March 2009

Prepared for:

U.S. Department of Energy

National Nuclear Security Administration

Nevada Site Office

\section{Prepared by:}

Lance Prothro, Sigmund Drellack, and Margaret Townsend

Underground Test Area and Boreholes Programs and Operations

Environmental Restoration

National Security Technologies, LLC

Las Vegas, Nevada 


\section{DISCLAIMER STATEMENT}

Reference herein to any specific commercial product, process, or service by trade name, trademark, manufacturer, or otherwise, does not necessarily constitute or imply its endorsement, recommendation, or favoring by the U.S. Government or any agency thereof or its contractors or subcontractors.

\section{AVAILABILITY STATEMENT}

Available to the public, in paper from-

U.S. Department of Commerce

National Technical Information Service

5285 Port Royal Road

Springfield, VA 22161-0002

Telephone: 800.553.6847

Fax: 703.605.6900

E-mail: orders@ntis.gov

Online ordering: http://www.ntis.gov/ordering.htm

Available electronically at http://www.osti.gov/bridge

Available for a processing fee to U.S. Department of Energy and its contractors, in paper, from-

\section{U.S. Department of Energy}

Office of Scientific and Technical Information

P.O. Box 62

Oak Ridge, TN, 37831-0062

Telephone: 865.576.8401

Fax: 865.576.5728

E-mail: reports@adonis.osti.gov 


\title{
Identification and Characterization of Hydrogeologic Units at the Nevada Test Site Using Geophysical Logs:
}

\section{Examples from the Underground Test Area Sub-Project}

\author{
Prepared for: \\ U.S. Department of Energy \\ National Nuclear Security Administration \\ Nevada Site Office \\ Las Vegas, Nevada \\ Prepared by: \\ Lance Prothro, Sigmund Drellack, and Margaret Townsend \\ Underground Test Area and Boreholes Programs and Operations \\ National Security Technologies, LLC \\ Las Vegas, Nevada
}

March 2009 
This page intentionally left blank. 


\section{ABSTRACT}

The diverse and complex geology of the Nevada Test Site region makes for a challenging environment for identifying and characterizing hydrogeologic units penetrated by wells drilled for the U.S. Department of Energy, National Nuclear Security Administration, Underground Test Area (UGTA) Environmental Restoration Sub-Project. Fortunately, UGTA geoscientists have access to large and robust sets of subsurface geologic data, as well as a large historical knowledge base of subsurface geological analyses acquired mainly during the underground nuclear weapons testing program. Of particular importance to the accurate identification and characterization of hydrogeologic units in UGTA boreholes are the data and interpretation principles associated with geophysical well logs. Although most UGTA participants and stakeholders are probably familiar with drill hole data such as drill core and cuttings, they may be less familiar with the use of geophysical logs; this document is meant to serve as a primer on the use of geophysical logs in the UGTA project.

Standard geophysical logging tools used in the UGTA project to identify and characterize hydrogeologic units are described, and basic interpretation principles and techniques are explained. Numerous examples of geophysical log data from a variety of hydrogeologic units encountered in UGTA wells are presented to highlight the use and value of geophysical logs in the accurate hydrogeologic characterization of UGTA wells. 
This page intentionally left blank. 


\section{Table of Contents}

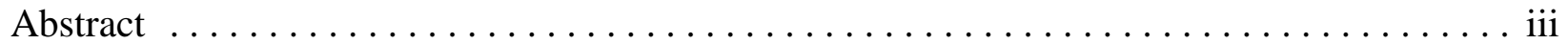

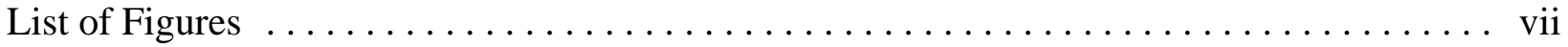

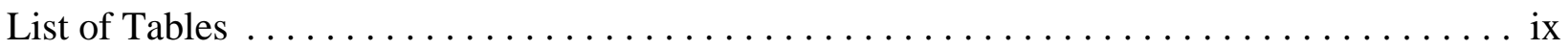

List of Acronyms and Abbreviations $\ldots \ldots \ldots \ldots \ldots \ldots \ldots \ldots \ldots \ldots \ldots \ldots \ldots \ldots \ldots \ldots \ldots \ldots$

$1.0 \quad$ Introduction $\ldots \ldots \ldots \ldots \ldots \ldots \ldots \ldots \ldots \ldots \ldots \ldots \ldots \ldots \ldots \ldots \ldots \ldots .1-1$

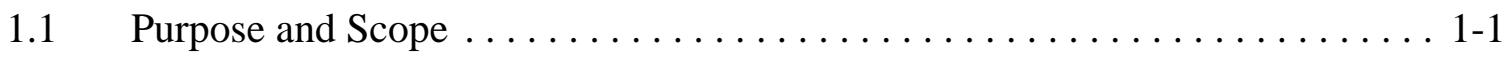

1.2 Overview of Hydrogeologic Units at the NTS $\ldots \ldots \ldots \ldots \ldots \ldots \ldots \ldots .1-1$

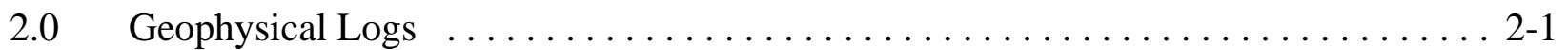

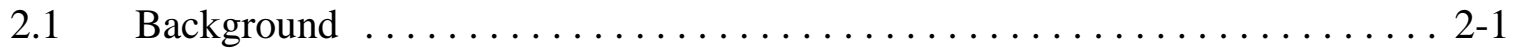

2.2 Geophysical Logging at the NTS . ....................... 2-1

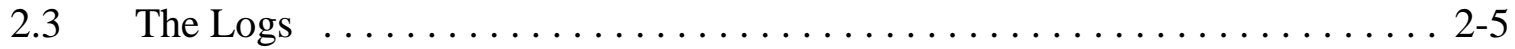

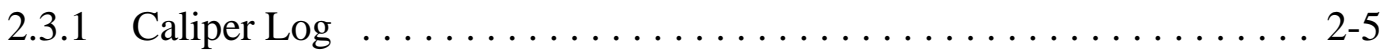

2.3.2 Gamma-Ray and Spectral Gamma-Ray Logs $\ldots \ldots \ldots \ldots \ldots \ldots .2-8$

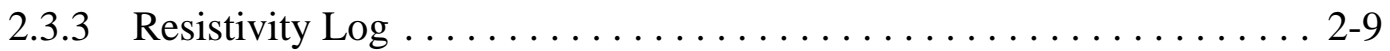

2.3.4 Density Log and the Photoelectric Effect $\ldots \ldots \ldots \ldots \ldots \ldots . . \ldots 2-9$

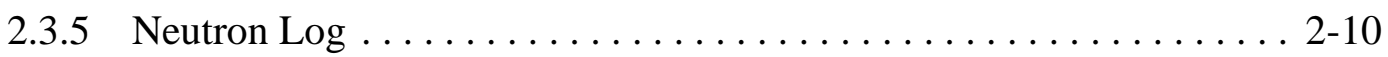

2.3.6 Combination Neutron-Density $\log \ldots \ldots \ldots \ldots \ldots \ldots \ldots \ldots . \ldots \ldots \ldots$

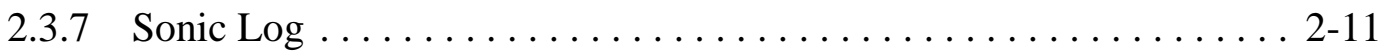

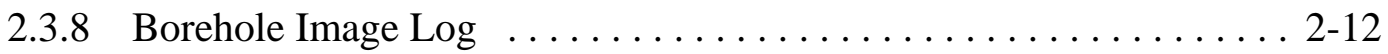

3.0 Examples of Geophysical Log Responses in NTS HGUs . . . . . . . . . . . . . . 3-1

3.1 Welded-Tuff Aquifer in Well ER-5-4 \#2 . ................... 3-1

3.2 Tuff Confining Units and Welded-Tuff Aquifer in Well ER-EC-1 . . . . . . . 3-3

3.3 Vitric-Tuff Aquifer and Tuff Confining Unit in Well ER-2-1 . . . . . . . 3-6

3.4 Lava-Flow Aquifer and Tuff Confining Units in Well ER-20-5 \#3 . . . . . . 3-9

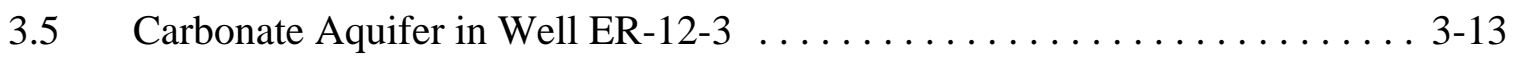

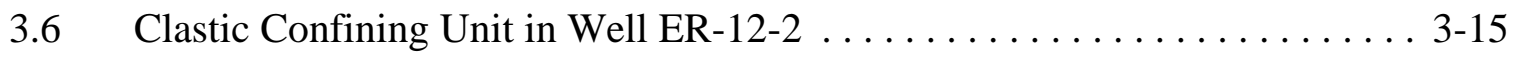

3.7 Contact Between Tuff Confining Unit and Carbonate Aquifer in Well ER-5-3 \#2 . . . . . . . . . . . . . . . . . . . . . . . . . . . 3-15

3.8 Contact Between Alluvial Aquifer and Welded-Tuff Aquifer in Well ER-5-3 ............................... 3-22

3.9 Correlating WTAs Between Wells ER-5-3 and ER-5-4 \#2 . . . . . . . . . 3-22 


\section{Table of Contents, continued}

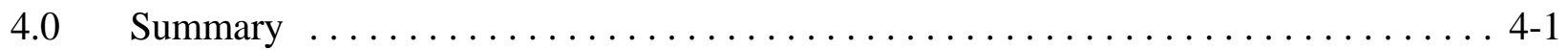

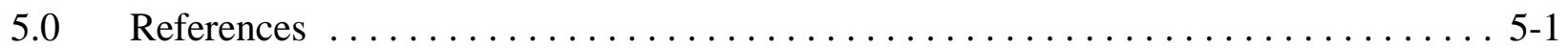

Distribution List $\ldots \ldots \ldots \ldots \ldots \ldots \ldots \ldots \ldots \ldots \ldots \ldots \ldots \ldots \ldots$. . . . . . . . . . . . . .

Appendix A List of References Related to the Development of Geophysical Logging

Techniques at the Nevada Test Site 


\section{List of Figures}

Number

Title

Page

1-1 Distribution of Drill Holes at the Nevada Test Site and Surrounding Areas that have been Drilled or Utilized in Support of DOE Activities ................ 1-2

2-1 Example of a Geophysical Well Log from Well ER-12-2 Showing Log Header, Data Scales, and a Portion of the Data Curves .................... 2-2

$2-2$ Diagram of Halliburton's Combination Neutron-Density Tool $\ldots . \ldots \ldots \ldots \ldots .2-3$

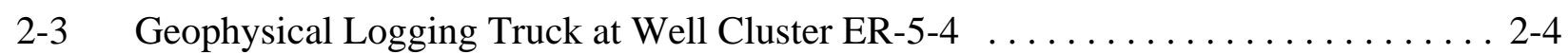

2-4 A Portion of the Borehole Image Log from UGTA Well ER-16-1 Showing a Fracture within Highly Bedded Shale $\ldots \ldots \ldots \ldots \ldots \ldots \ldots \ldots \ldots \ldots . . \ldots \ldots$

3-1 Portions of the Gamma-Ray and Resistivity Logs for Well ER-5-4 \#2 $\ldots \ldots \ldots \ldots$ 3-2

3-2 Portions of the Neutron- and Density-Derived Porosity Logs for Well ER-5-4 \#2 ‥ 3-4

3-3 Portions of the Resistivity and Gamma-Ray Logs from Well ER-EC-1 . . . . . . . 3-5

3-4 Portions of the Sonic, Neutron, and Density Logs from Well ER-EC-1 . . . . . . . . 3-7

3-5 Portions of the Borehole Image and Density Logs from Well ER-2-1 . . . . . . 3-8

3-6 Exposure of the Lower Portion of the Rainier Mesa Tuff in Area 19 of the NTS Showing a Geologic Section Similar to that Logged in Well ER-2-1 and

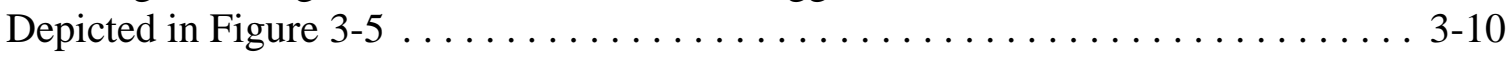

3-7 Portions of the Gamma-Ray and Deep Laterolog from Well ER-20-5 \#3 . . . . . . 3-11

3-8 Portions of the Density, Neutron, and Sonic Logs from Well ER-20-5 \#3 . . . . . . 3-12

3-9 Portions of the Gamma-Ray and Combination Neutron-Density Logs From

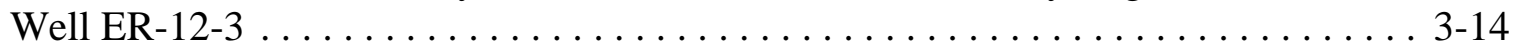

3-10 Bottom Portion of the Gamma-Ray Log from Well ER-12-2 . . . . . . . . . . . 3-16

3-11 Contact Between Tuff Confining Unit and Carbonate Aquifer above the E-Tunnel Portal in Area 12 ............................... 3-18

3-12 Portions of the Gamma-Ray and Laterolog from Well ER-5-3 \#2 . . . . . . . . 3-19

3-13 Portions of the Sonic and Combination Neutron-Density Logs from

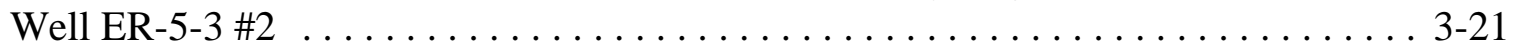

3-14 Bottom Portions of the Gamma-Ray Log and Laterolog from Well ER-5-3 . . . . 3 3-23

3-15 Portions of the Laterologs from Wells ER-5-3 and ER-5-4 \#2 Showing the Excellent Correlation of WTAs within the Timber Mountain Group . . . . . . . . 3-25 
This page intentionally left blank. 


\section{List of Tables}

Number

Title

Page

1-1 Hydrogeologic Units of the Nevada Test Site . . . . . . . . . . . . . . . . 1-4

2-1 Descriptions of Geophysical Logs . . . . . . . . . . . . . . . . . . . . 2-6 
This page intentionally left blank. 


\section{List of Acronyms and Abbreviations}

\begin{tabular}{|c|c|}
\hline AA & alluvial aquifer \\
\hline API & American Petroleum Institute \\
\hline $\mathrm{BN}$ & Bechtel Nevada \\
\hline CA & carbonate aquifer \\
\hline CAU & corrective action unit \\
\hline CCU & clastic confining unit \\
\hline CPS & count(s) per second \\
\hline $\mathrm{ft}$ & foot (feet) \\
\hline $\mathrm{G} / \mathrm{CM}^{3}$ & gram(s) per cubic centimeter \\
\hline GCU & granite confining unit \\
\hline HFM & hydrostratigraphic framework model \\
\hline HGU & hydrogeologic unit \\
\hline HSU & hydrostratigraphic unit \\
\hline IICU & intra-caldera confining unit \\
\hline $\mathrm{IT}$ & IT Corporation \\
\hline $\mathrm{km}$ & kilometer \\
\hline LFA & lava-flow aquifer \\
\hline $\mathrm{m}$ & meter(s) \\
\hline mi & mile(s) \\
\hline NNSA/NSO & $\begin{array}{l}\text { U.S. Department of Energy, National Nuclear Security Administration Nevada } \\
\text { Site Office }\end{array}$ \\
\hline NSTec & National Security Technologies, LLC \\
\hline NTS & Nevada Test Site \\
\hline OHMM & ohm-meter(s) \\
\hline PCU & playa confining unit \\
\hline $\mathrm{PE}$ & photoelectric effect \\
\hline TCU & tuff confining unit \\
\hline UGTA & Underground Test Area \\
\hline US/FT & microsecond(s) per foot \\
\hline VTA & vitric-tuff aquifer \\
\hline WTA & welded-tuff aquifer \\
\hline
\end{tabular}


This page intentionally left blank. 


\subsection{Introduction}

Hydrostratigraphic framework models (HFMs) constructed for the U.S. Department of Energy, National Nuclear Security Administration Nevada Site Office (NNSA/NSO) Underground Test Area (UGTA) Environmental Restoration Sub-Project rely heavily on subsurface information from drill holes. Thousands of boreholes have been drilled at the Nevada Test Site (NTS) since the early 1950s (Figure 1-1), and many of the holes provide critical data on the nature and extent of geologic units buried by hundreds of meters of younger rocks. Most UGTA participants and stakeholders are familiar with drill hole data such as drill core and cuttings. However, they may be less familiar with the use of geophysical logs; yet these data are critical in identifying, characterizing, and correlating hydrogeologic units (HGUs) and hydrostratigraphic units (HSUs) at the NTS.

\subsection{Purpose and Scope}

This report provides examples of how geophysical logs are used to help identify and characterize HGUs in UGTA wells. It is intended to provide UGTA participants and stakeholders who may be unfamiliar with geophysical logs a basic knowledge and appreciation of NTS geophysical log data, particularly its application to the characterization of HGUs penetrated in NTS boreholes. The main emphasis of the report is the application of standard geophysical log data in the recognition and evaluation of geologic features that control the hydrogeologic categorization of NTS rock units. Other log data, such as temperature and flow logs, used to evaluate flow characteristics are not addressed in this report. The report also does not address geophysical tools used to determine borehole inclination, those used to determine the quality of casing cement jobs, or other well-construction-related tools; and this report is not intended to be a detailed instructional document on geophysical log interpretation. Readers interested in more details on log interpretation principals and applications are referred to Hilchie (1978), Merkel (1983), and Asquith and Krygowski (2004), as well as NTS-specific reports listed in Section 5.0 of this report. For details on the specifications and operations of various logging tools, the reader is referred to product documents from the various well logging service companies.

\subsection{Overview of Hydrogeologic Units at the NTS}

The accurate hydrogeologic categorization of NTS rock units into HGUs is a critical step in establishing HSUs and developing UGTA HFMs. HFMs are developed using a two-level hydrostratigraphic system consisting of HGUs that are grouped into larger HSUs that form 


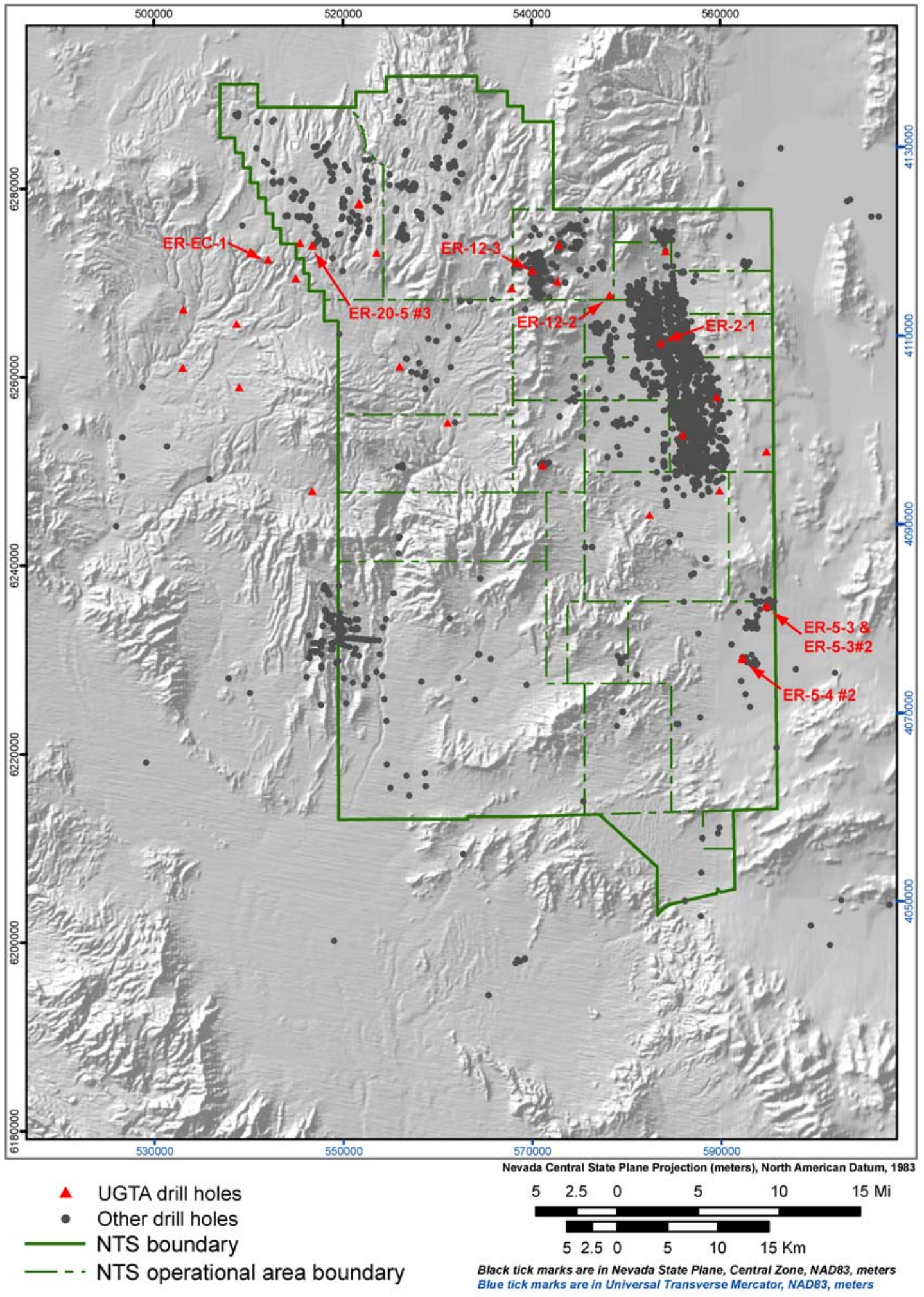

Figure 1-1

Distribution of Drill Holes at the Nevada Test Site and Surrounding Areas that have been Drilled or Utilized in Support of U.S. Department of Energy Activities (Drill holes discussed in this report are labeled.) 
the unit volumes of the HFMs (National Security Technologies, LLC [NSTec], 2007; 2008). At the scale of the UGTA Corrective Action Unit (CAU) hydrostratigraphic system, HGUs categorize rock units as aquifers and confining units according to their porosity and permeability. Rocks in the NTS area are classified as one of ten HGUs (Table 1-1) based mainly on the rock's primary lithology, type and degree of post-depositional alteration, and propensity to fracture (Winograd and Thordarson, 1975; IT Corporation [IT], 1996; Laczniak et al., 1996; Bechtel Nevada [BN], 2005; 2006; NSTec, 2007; 2008; and Prothro et al., 2009). Fortunately, these geologic characteristics influence various geophysical log measurements and, thus, allow the use of logs to help in the delineation and characterization of HGUs. 
Table 1-1

Hydrogeologic Units of the Nevada Test Site

(Adapted from Winograd and Thordarson [1975]; IT [1996]; and Laczniak et al. [1996])

\begin{tabular}{|c|c|c|}
\hline Hydrogeologic Unit & Typical Lithologies & Hydrologic Significance \\
\hline $\begin{array}{l}\text { Alluvial aquifer } \\
\qquad \text { (AA) }\end{array}$ & $\begin{array}{l}\text { Unconsolidated to partially } \\
\text { consolidated gravelly sand, } \\
\text { eolian sand, and colluvium }\end{array}$ & $\begin{array}{l}\text { Has characteristics of a highly conductive aquifer, } \\
\text { but less so where lenses of clay-rich } \\
\text { paleocolluvium or zeolitic alteration are present. }\end{array}$ \\
\hline $\begin{array}{l}\text { Welded-tuff aquifer } \\
\text { (WTA) }\end{array}$ & $\begin{array}{l}\text { Welded ash-flow tuff; vitric } \\
\text { to devitrified }\end{array}$ & $\begin{array}{l}\text { Degree of welding greatly affects interstitial } \\
\text { porosity (i.e., less matrix porosity as degree of } \\
\text { welding increases) and permeability (i.e., greater } \\
\text { fracture permeability as degree of welding } \\
\text { increases). }\end{array}$ \\
\hline $\begin{array}{l}\text { Vitric-tuff aquifer } \\
\text { (VTA) }\end{array}$ & $\begin{array}{l}\text { Bedded tuff; ash-fall and } \\
\text { reworked tuff; vitric }\end{array}$ & $\begin{array}{l}\text { Constitutes a volumetrically minor HGU. Generally } \\
\text { does not extend far below the static water level due } \\
\text { to tendency of tuff to become zeolitic under } \\
\text { saturated conditions, which drastically reduces } \\
\text { permeability. Typically very poorly fractured. }\end{array}$ \\
\hline $\begin{array}{l}\text { Lava-flow aquifer } \\
\text { (LFA) }\end{array}$ & $\begin{array}{l}\text { Rhyolite, basalt and dacite } \\
\text { lava flows; flow breccia } \\
\text { (commonly at base) }\end{array}$ & $\begin{array}{l}\text { Generally occurs as small, moderately thick } \\
\text { (rhyolite) to thin (basalt) local flows. Hydrologically } \\
\text { complex, showing a wide range of transmissivity } \\
\text { values. Fracture density and interstitial porosity } \\
\text { differ with lithologic variations. }\end{array}$ \\
\hline $\begin{array}{l}\text { Playa confining unit } \\
\text { (PCU) }\end{array}$ & Silt and clay & $\begin{array}{l}\text { Near-surface confining unit at Yucca and } \\
\text { Frenchman Lakes and within lower portion of } \\
\text { alluvial section in the deepest portions of } \\
\text { Frenchman Flat. }\end{array}$ \\
\hline $\begin{array}{l}\text { Tuff confining unit } \\
\text { (TCU) }\end{array}$ & $\begin{array}{l}\text { Zeolitic bedded tuff with } \\
\text { interbedded, but less } \\
\text { significant, zeolitic, } \\
\text { nonwelded to partially } \\
\text { welded ash-flow tuff }\end{array}$ & $\begin{array}{l}\text { May be saturated but measured transmissivity } \\
\text { values are very low. May cause semi-perched } \\
\text { conditions. }\end{array}$ \\
\hline $\begin{array}{l}\text { Intra-caldera intrusive } \\
\text { confining unit (IICU) }\end{array}$ & $\begin{array}{l}\text { Highly altered, highly } \\
\text { injected/intruded country } \\
\text { rock and granitic material }\end{array}$ & $\begin{array}{l}\text { Assumed to be impermeable. Conceptually } \\
\text { underlies each of the calderas of the southwest } \\
\text { Nevada volcanic field. Developed to designate } \\
\text { basement beneath calderas as different from } \\
\text { basement outside calderas. }\end{array}$ \\
\hline $\begin{array}{l}\text { Granite confining unit } \\
\text { (GCU) }\end{array}$ & Quartz monzonite & $\begin{array}{l}\text { Saturated at depth, but because of low } \\
\text { intergranular porosity and permeability, plus the } \\
\text { lack of inter-connecting fractures, is considered a } \\
\text { confining unit. }\end{array}$ \\
\hline $\begin{array}{l}\text { Clastic confining unit } \\
(\mathrm{CCU})\end{array}$ & Argillite, siltstone, quartzite & $\begin{array}{l}\text { Siliciclastic rocks are relatively impermeable; } \\
\text { coarser-grained siliciclastic rocks are fractured, but } \\
\text { with fracture porosity generally sealed due to } \\
\text { secondary mineralization. }\end{array}$ \\
\hline $\begin{array}{l}\text { Carbonate aquifer } \\
\text { (CA) }\end{array}$ & Dolomite, limestone & $\begin{array}{l}\text { Transmissivity values vary greatly and are directly } \\
\text { dependent on fracture frequency. }\end{array}$ \\
\hline
\end{tabular}




\subsection{Geophysical Logs}

\subsection{Background}

A geophysical well log is a record of physical measurements made at different depths in a borehole, which can be used to determine the characteristics of the rocks and fluids in the borehole, or the characteristics of the borehole itself (Figure 2-1). Typically, several different logs are run in the same hole (i.e., a logging suite) to provide information for a wide range of parameters. Geophysical logging tools are long cylindrical rod-shaped devices that are lowered into a borehole via a diagnostic cable attached to a winch on the back of a recording truck (Figures 2-2 and 2-3). Actual logging of a hole occurs as the tool is pulled up the hole at a specified speed. Most modern logging operations use a "stacked" configuration, where multiple logging tools are attached to each other to form a single string of tools. This arrangement allows multiple types of log data to be acquired in a single logging run.

Geophysical logging techniques used at the NTS had their origin in the petroleum and mining industries and are widely used in subsurface geologic investigations throughout the world. Borehole logging tools have been used to characterize subsurface earth materials since the 1920s when the first log was made of variations in electrical response at different depths in a borehole, which was then correlated to rock types penetrated in the hole (Gatlin, 1960). The well-logging industry advanced quickly and developed other tools that measure a variety of rock and fluid characteristics in boreholes, such as a rock's response to bombardment by radiation or acoustic waves. Currently, a wide array of geophysical logging tools is available to suit nearly any geologic condition and data requirement. Numerous specialty well logging companies provide these services, using industry-wide standards for calibration and quality control.

\subsection{Geophysical Logging at the NTS}

Geophysical logs have been used extensively by NTS geologists since the 1950s to characterize and evaluate the geology of NTS boreholes. The national weapons laboratories and the U.S. Geological Survey worked with private well-logging companies to develop a sophisticated understanding of how log responses correlate to rock properties at the NTS. Standard logs and interpretation principals used by the petroleum industry in sedimentary rock settings were adapted for use in the volcanic rocks of the NTS area and for the large diameter holes commonly drilled at the NTS. Although techniques evolved over time as down-hole technology advanced, there is a continuity and consistency to down-hole geologic interpretations since the early drilling operations and geologic investigations at the NTS. Many NTS-specific references 

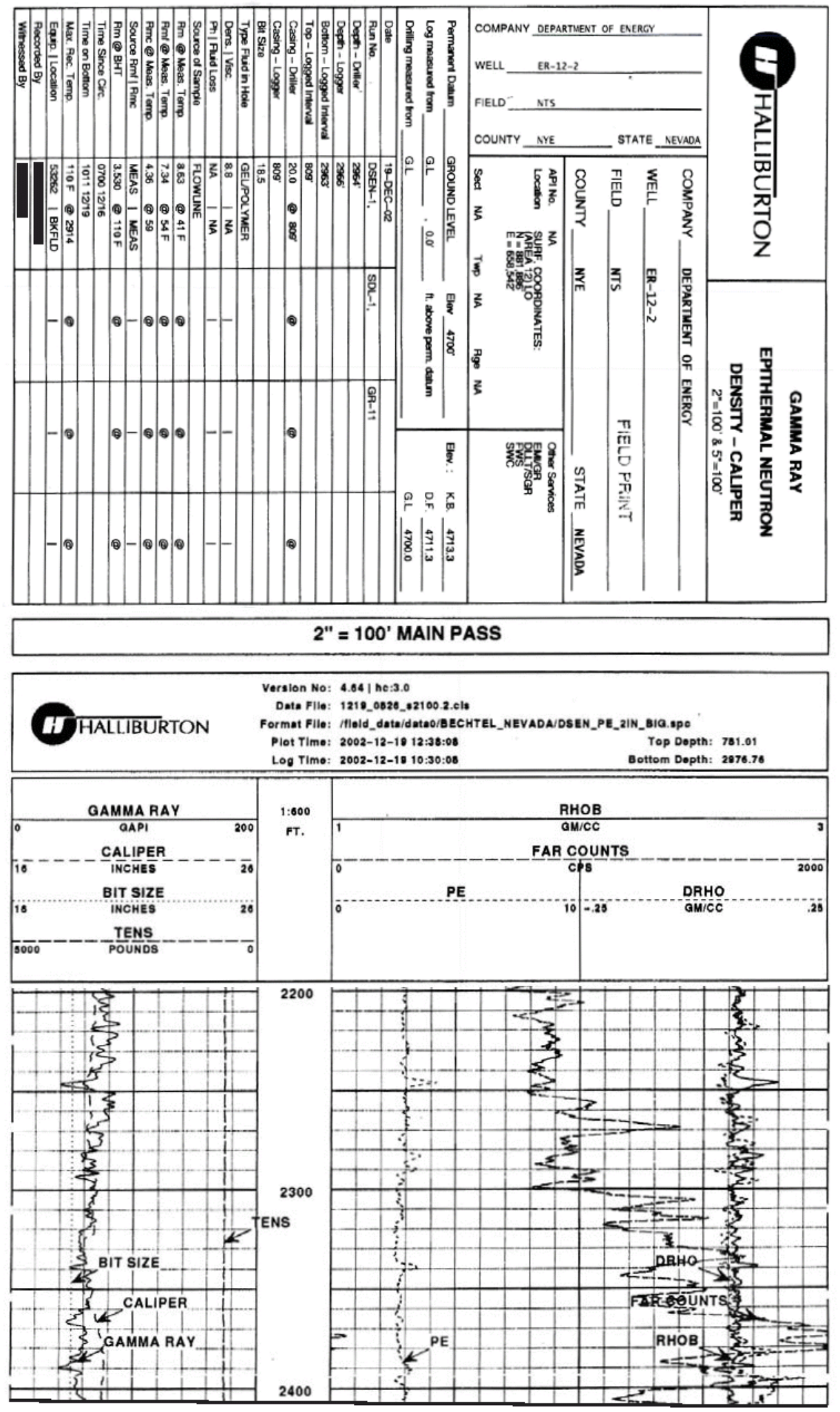

Figure 2-1

Example of a Geophysical Well Log from Well ER-12-2 Showing Log Header, Data Scales, and a Portion of the Data Curves 


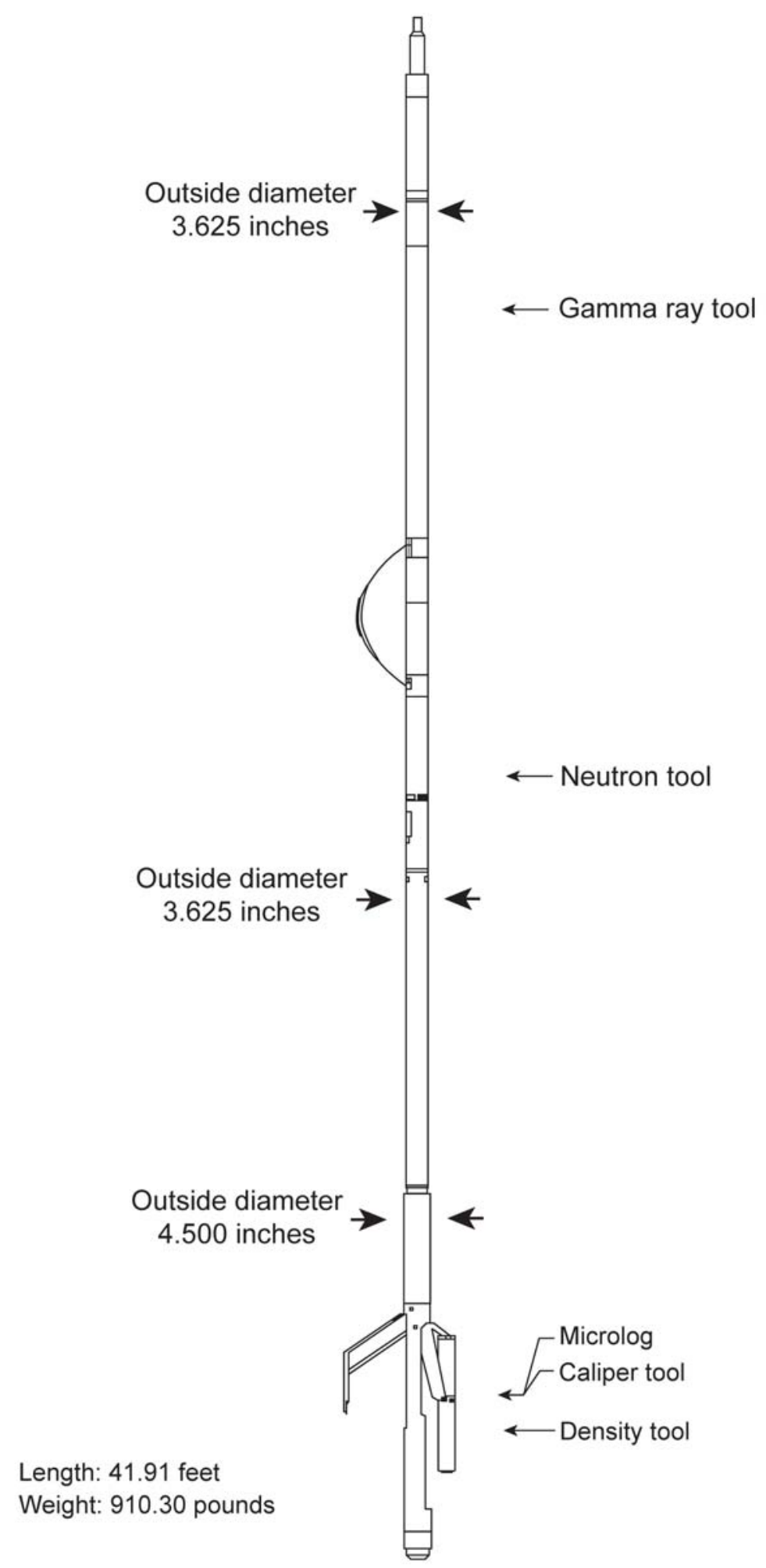

Figure 2-2

Diagram of Halliburton's Combination Neutron-Density Tool 

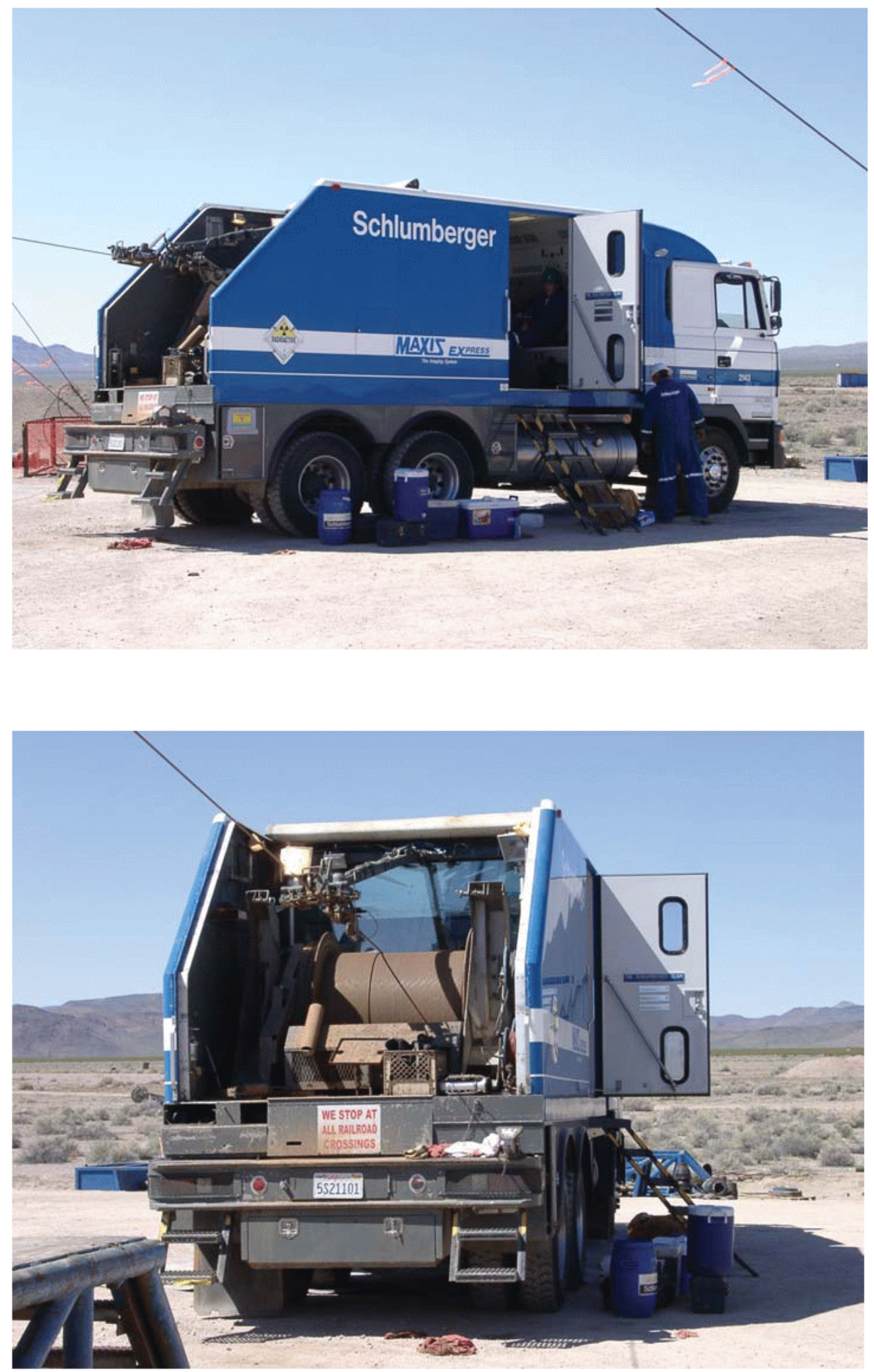

Figure 2-3

Geophysical Logging Truck at Well Cluster ER-5-4 
are available that discuss development and use of specific geophysical tools and techniques for NTS applications related to underground nuclear testing. Citations for these are listed in Appendix A.

Many of the geophysical log interpretation principals used for subsurface hydrogeologic studies for the UGTA project were developed specifically to support historic underground nuclear testing in alluvium and volcanic rocks. Development of these techniques and the highly evolved understanding of the use of geophysical log responses to identify the physical character of rocks at the NTS led to our modern reliance on specific suites of geophysical logs to supplement observational data from samples (e.g., drill cuttings). The same characterization information required by the underground testing program is directly applicable to interpretation and characterization of HGUs for the UGTA project, so there exists a very large, "ready-made" data set of geophysical log data for the NTS that the UGTA project has been using and adding to since its inception.

\subsection{The Logs}

Standard geophysical logging tools used by the UGTA project to identify and characterize HGUs fall into several main categories based on the physical characteristics of the borehole or earth materials being measured: caliper logs, gamma-ray logs, electric logs, porosity logs (i.e., density, neutron, and sonic), and image logs. Summary information about these logs is presented in Table 2-1. More detailed descriptions, including some basic interpretation principals, are provided in the following sections. Much of the information presented in this section is from Merkel (1983) and Asquith and Krygowski (2004).

\subsubsection{Caliper Log}

Caliper logging tools measure the diameter of a borehole. This measurement is obtained by converting the mechanical movement of spring-loaded arms into electrical signals. Most caliper tools have one to six spring-loaded arms. Three-arm tools have arms at 120-degree intervals around the tool and, thus, measure the average diameter of the borehole. Six-arm tools have six spring-loaded arms at 60-degree intervals around the tool, with opposite arms paired so that three hole diameters are measured at any given depth. Caliper tools may be run in air-filled or fluidfilled boreholes. In addition to general borehole conditions, caliper log data are necessary for more accurate interpretation of other geophysical logs. Most logging tools are influenced to some degree by borehole diameter and perturbations in the borehole wall, and caliper data may be used to compensate for borehole effects on other logs. 
Table 2-1

Descriptions of Geophysical Logs

\begin{tabular}{|c|c|c|}
\hline Log Type & Description $^{a}$ & $\begin{array}{c}\text { Main Uses in Hydrogeologic Characterization } \\
\text { of UGTA HGUs }\end{array}$ \\
\hline Caliper & $\begin{array}{l}\text { Measures the diameter of a borehole using one to six spring- } \\
\text { loaded arms. }\end{array}$ & $\begin{array}{l}\text { Determination of borehole washouts and other borehole wall } \\
\text { perturbations that may affect other log readings. Lithologic } \\
\text { and fracture identification. }\end{array}$ \\
\hline Gamma Ray & $\begin{array}{l}\text { Measures the radioactivity of rocks in a borehole, which is } \\
\text { typically the result of gamma rays produced by potassium- } 40 \text { and } \\
\text { the decay daughter products of the uranium and thorium series. }\end{array}$ & $\begin{array}{l}\text { Distinguishing between volcanic and sedimentary units, and } \\
\text { between shale and "clean" sedimentary rocks like carbonate } \\
\text { and quartzite. Confirmation of welding in ash-flow tuffs. }\end{array}$ \\
\hline Resistivity & $\begin{array}{l}\text { Measures the response of a formation to an electric current } \\
\text { emitted and measured by way of electrodes or induction coils. } \\
\text { Electrode tools (e.g., laterologs) have electrodes on the surface of } \\
\text { the tool that measure the resistivity of a formation. Induction tools } \\
\text { use coils to induce a current and measure a formation's } \\
\text { conductivity. Both tools measure the ability of a rock formation to } \\
\text { transmit an electric current, which is typically a function of the } \\
\text { amount of water in a formation and the chemical composition of } \\
\text { the water. }\end{array}$ & $\begin{array}{l}\text { Identification of alteration in volcanic rocks, such as } \\
\text { zeolitization and argillization. Recognition of zones of } \\
\text { welding in ash-flow tuffs. Distinguishing low-porosity HGUs } \\
\text { such as welded-tuff aquifers (WTA), lava-flow aquifers } \\
\text { (LFA), and carbonate aquifers (CA) from high porosity (or } \\
\text { high water content) HGUs such as vitric-tuff aquifers (VTA), } \\
\text { tuff confining units (TCU), and clastic confining units (CCU). }\end{array}$ \\
\hline Density & $\begin{array}{l}\text { Measures the bulk density of a formation by emitting gamma rays } \\
\text { into the formation and recording the amount of returning high } \\
\text { energy gamma rays. The number of gamma rays returned in the } \\
\text { high energy range is inversely proportional to the electron density } \\
\text { of the formation, which is related to the bulk density of the } \\
\text { formation. }\end{array}$ & $\begin{array}{l}\text { Determination of total porosity. Determination of the degree } \\
\text { of welding in ash-flow tuffs. Distinguishing denser and lower } \\
\text { porosity HGUs such as WTA, LFA, and CA from less dense } \\
\text { and higher porosity (or high water content) HGUs such as } \\
\text { VTA, TCU, and CCU. In combination with neutron data, is } \\
\text { an excellent lithologic indicator in sedimentary rocks. }\end{array}$ \\
\hline Neutron & $\begin{array}{l}\text { Measures the hydrogen-ion concentration of a formation by } \\
\text { emitting neutrons into the formation and recording the amount of } \\
\text { returning neutron energy. The amount of returning neutron } \\
\text { energy recorded by the tool detectors is inversely proportional to } \\
\text { the amount of water in the formation, which is typically a function } \\
\text { of formation porosity. }\end{array}$ & $\begin{array}{l}\text { Determination of total porosity. Identification of alteration in } \\
\text { volcanic rocks, such as zeolitization and argillization. } \\
\text { Distinguishing lower porosity HGUs such as WTA, LFA, and } \\
\text { CA from higher porosity (or high water content) HGUs such } \\
\text { as VTA, TCU, and CCU. In combination with density data, is } \\
\text { an excellent lithologic indicator in sedimentary rocks. }\end{array}$ \\
\hline
\end{tabular}


Table 2-1

Descriptions of Geophysical Logs (continued)

\begin{tabular}{|c|c|c|}
\hline Log Type & Description $^{a}$ & $\begin{array}{c}\text { Main Uses in Hydrogeologic Characterization } \\
\text { of UGTA HGUs } \\
\end{array}$ \\
\hline Sonic & $\begin{array}{l}\text { Measures the time it takes for an acoustic wave to travel through } \\
\text { a formation along the borehole wall, termed interval travel time. } \\
\text { Interval travel time is dependent on lithology, porosity, and pore- } \\
\text { fluid composition. }\end{array}$ & $\begin{array}{l}\text { Determination of primary matrix porosity. Distinguishing } \\
\text { lower porosity HGUs, such as WTA, LFA, and CA, from } \\
\text { higher porosity (or high water content) HGUs, such as VTA, } \\
\text { TCU, and CCU. }\end{array}$ \\
\hline $\begin{array}{l}\text { Borehole } \\
\text { Image }\end{array}$ & $\begin{array}{l}\text { Provides an electronic image of the borehole wall using either } \\
\text { electric, acoustic, or video logging tools. Because the images are } \\
\text { oriented with respect to compass direction, the orientation (i.e., } \\
\text { strike and dip) of planar features can be determined and } \\
\text { analyzed. }\end{array}$ & $\begin{array}{l}\text { Structural analysis, including fracture characterization. } \\
\text { Recognition of lithologic features. }\end{array}$ \\
\hline
\end{tabular}

a From Asquith and Krygowski (2004) and Merkel (1983) 
Caliper logs can also be used in some cases to help discriminate between different lithologic units. Soft and poorly consolidated rocks, such as vitric ash-fall and reworked tuffs, tend to be susceptible to caving and hole erosion during drilling. These rocks typically give a smooth but out-of-gauge (i.e., enlarged borehole diameter) caliper signature. More consolidated rocks, such as zeolitic ash-fall and reworked tuffs, will typically have smooth and in-gauge caliper signatures. Harder and more consolidated rocks, such as welded ash-flow tuff, lava, and carbonate will have smooth in-gauge signatures where relatively unfractured. Highly fractured intervals, however, can result in blocky caving of the borehole wall during drilling, resulting in abrupt borehole enlargements or a "ragged" caliper log signature. Thus, caliper logs can sometimes provide an indication of fractures in a borehole.

\subsubsection{Gamma-Ray and Spectral Gamma-Ray Logs}

Gamma-ray logs measure the radioactivity of rocks in a borehole. Nearly all of the natural background radiation in rocks is the result of gamma rays produced by potassium- 40 and the decay daughter products of the uranium and thorium series. Total gamma-ray data are presented as counts per minute (or second), or in the more universally correlatable American Petroleum Institute (API) units. Gamma-ray logs can be run in boreholes filled with any type of fluid, and are generally little affected by irregularities in the borehole wall.

The gamma-ray log is particularly useful in helping to delineate shale from carbonate and quartzite, because shale typically has higher concentrations of potassium-40. Because volcanic rocks are typically more radioactive than sedimentary rocks, the gamma-ray log is commonly used at the NTS to help determine important stratigraphic contacts such as those between alluvium and volcanic rocks and between volcanic rocks and pre-Tertiary rocks.

The spectral gamma-ray log is a special type of gamma-ray log that measures gamma rays within pre-selected energy windows, and therefore can determine the amount of gamma rays resulting from the radioactive decay of each of the three major sources (i.e., potassium-40, the thorium series, and the uranium series), as well as other sources. Data from the three major sources are typically presented in percent for potassium and parts per million for thorium and uranium. At the NTS the spectral gamma-ray log is typically used to help establish precise stratigraphic contacts and as an indicator of possible fractures, which are sometimes represented as higher spikes on the uranium curve. 


\subsubsection{Resistivity Log}

Resistivity logs measure the ability of a rock formation to conduct an electric current. Except for metallic minerals, most minerals that compose rock formations are electrical insulators, or resistors. Typically, the only substance in a formation that will conduct electricity is the water contained in interstitial pore spaces, fractures, and adsorbed water on clay particles. The resistivity of most rock formations is therefore dependent on two main factors: the amount of water-filled porosity and the resistivity of that water (i.e., chemical composition).

Resistivity tools are designed to impart an electric current into the formation and measure the response of the formation to that current. Resistivity is typically reported on logs as ohm-meters (OHMM). Although there are many varieties of resistivity tools, they generally fall into two categories: electrode and induction. Modern electrode tools use numerous electrodes on the tool that emit an electric current into the formation and measure a formation's resistivity. The spacing of the electrodes along the tool influences the depth of investigation within the formation. Induction tools utilize a coiled arrangement to induce an electric current into the formation. The advantage of this coiled arrangement is that the induction resistivity tool can be run in air-filled holes. As with the electrode tool, different depths of investigation can be achieved with the induction tool by varying the arrangement and spacing of the transmitting and receiving coils.

Resistivity logs are mainly used in the petroleum industry to delineate hydrocarbon-bearing zones from water-bearing zones. At the NTS, resistivity logs are particularly useful in delineating aquifers from confining units. The resistivity of TCUs and shale-dominated CCUs are typically much lower than that of WTAs, LFAs, and CAs.

\subsubsection{Density Log and the Photoelectric Effect}

The density log is typically used to determine the porosity of rocks by measuring the electron density of rocks penetrated by a borehole. The density tool uses a gamma-ray source and multiple gamma-ray detector pads that are held against the sides of the borehole. Gamma rays emitted into the formation by the density tool are scattered and deflected by collisions with electrons in the formation, which results in a loss of energy from the gamma-ray particles (i.e., Compton scattering). The number of returning higher energy gamma rays recorded by the detectors is inversely proportional to the electron density of the formation, which in turn is related to the bulk density of the formation, which is typically reported on density logs as grams per cubic centimeters $\left(\mathrm{G} / \mathrm{CM}^{3}\right)$. In other words, as formation bulk density increases, fewer higher energy gamma rays will reach the detectors. 
In the case of porous formations, the bulk density of a formation includes both the density of the fluid in the pore spaces and the matrix density of the rock, so porosity can be calculated from the density log data if accurate matrix and fluid density values are available. Porosity values obtained from density logs represent total porosity, including fractures and vugs if present. However, because the density tool uses a small sidewall pad for a detector and has a relatively shallow depth of investigation, it may underestimate porosity in fractured or vuggy formations. Most modern density tools are "compensated" to minimize the effects of mud cake, borehole size, and rugosity.

At the NTS, the density log is a valuable tool for distinguishing welded from nonwelded volcanic rocks. The welded portions of ash-flow tuffs that form WTAs are considerably denser than associated nonwelded zones that form VTAs or TCUs. The density log is considered to be an essential tool for deciphering the complex distribution of HGUs within rhyolitic lava flows such as those beneath Pahute Mesa.

The interactions of lower energy gamma rays are governed by the photoelectric effect (PE) and are strongly dependent on lithology. Most modern density logs provide a PE curve in the log presentation. Because it is dependent on lithology, the curve is an excellent lithologic indicator in common sedimentary rocks such as sandstone, carbonate, and dolomite, which have significantly different mineralogic compositions. Values for common sedimentary rocks in barns per electron are 5.08 for limestone, 3.14 for dolomite, and 1.81 for sandstone. The PE curve is less useful in volcanic rocks at the NTS because the basic mineralogic composition (i.e., mostly rhyolitic) of the volcanic rocks does not vary significantly.

\subsubsection{Neutron Log}

The neutron log is used to determine porosity by measuring the hydrogen-ion concentration in the formation. A radiochemical source in the neutron tool emits neutrons into the formation that collide with nuclei of the various elements within the formation. These collisions cause the neutrons to lose energy. Because hydrogen atoms are almost equal in mass to neutrons, maximum energy loss occurs when neutrons collide with hydrogen atoms. Detectors on the tool typically measure the returning neutron energy at either the thermal or the higher, epithermal, level, depending on the type of neutron tool used. Most logging operations at the NTS, including those for the UGTA project, have used epithermal neutron tools. Data are typically recorded on neutron logs as counts per second (CPS) or in API units. 
Because hydrogen in rocks is typically associated with fluid in pores, energy loss can be related to a formation's porosity. Thus, the greater amount of energy loss, the higher the fluid content, or porosity of the formation. Like the density tool, modern neutron tools are "compensated" to minimize borehole effects.

In most rocks at the NTS, the hydrogen ion content is directly proportional to the formation water content and, thus, porosity. However, in formations where hydrogen is bound at the molecular level, such as shale, gypsum, and zeolitic tuff, the neutron log will give anomalously high porosity values. Conversely, in unsaturated conditions where the pore space is not 100-percent filled with water, the neutron log will underestimate porosity, giving values that represent only moisture content. Also, like the density log, the neutron log provides total porosity but may underestimate porosity values in fractured and vuggy formations because the tool uses a small sidewall detector pad.

\subsubsection{Combination Neutron-Density Log}

It has become a standard industry practice to show the neutron and density data on the same log presentation. Besides the basic data curves of bulk density and neutron counts, density- and neutron-derived porosity curves are also presented. Porosity values are calculated from the basic log data using a single matrix value, typically limestone, and are presented as individual curves for density-derived porosity and neutron-derived porosity on the same log.

The combination neutron-density porosity log is an excellent lithologic indicator in sedimentary rocks. In limestone, the two curves overlay each other and provide a good estimate of formation porosity. Where the formation consists of rocks other than limestone, the two curves will not overlay but will have characteristic patterns according to formation lithology. For example, in dolomite, the curves separate, with the neutron porosity values higher than density-derived porosity. In sandstone formations, porosity from the density log will read higher than neutron porosity. In units other than limestone, porosity values read directly from the log must be corrected according to the lithology being logged. Although porosity correction charts and values are available for common sedimentary rocks, they are not available for other rock types (e.g., volcanic rocks).

\subsubsection{Sonic Log}

The sonic log is a porosity log that measures the time it takes for an acoustic wave to travel through the rock along the borehole wall. This interval travel time typically is reported as microseconds per foot (US/FT) on sonic logs. The sonic tool uses one or two transmitters and 
two or more receivers. Modern tools are compensated to correct for borehole effects and tool tilt. Interval travel time is dependent on lithology and porosity, including the pore fluid; thus, accurate interval travel times for the rocks being logged, as well as for the pore fluid, must be known to accurately calculate porosity. Sonic logs measure only primary matrix porosity. Secondary porosity, such as fracture porosity, is typically not measured by sonic logs. Consequently, porosity values calculated from the sonic log will tend to be unrealistically low, particularly in fractured rocks. In the right environment, porosity values from the sonic log can be subtracted from values determined from other porosity logs to derive an estimate of secondary porosity.

At the NTS, sonic logs are useful in delineating volcanic aquifers from confining units. WTAs and LFAs are well consolidated, fractured aquifers with typically low matrix porosity and, thus, have relatively fast interval transit times. On sonic logs, these aquifers contrast well with TCUs, which are characterized by relatively high interstitial porosity, low effective porosity, and relatively slow interval travel times.

\subsubsection{Borehole Image Log}

Borehole image logs provide an electronic image of the borehole wall using either electric, acoustic, or video logging tools. Image data are typically presented as folded-out, twodimensional color images of the inner walls of boreholes. Thus, planar features cutting through the borehole, such as fractures and bedding planes, are visible as sinusoidal traces in the image logs (Figure 2-4). Because the images are oriented with respect to compass direction, the orientation (i.e., strike and dip) of planar features can be determined and analyzed using special software programs.

As borehole image log technology has improved, image logs have become important tools for the characterization of HGUs at the NTS because many of the aquifers at the NTS are fractured aquifers (e.g., WTA, LFA, and CA). Borehole image logs provide the only means to characterize fractures, particularly orientation, in the absence of oriented core samples. Image logs can provide indications of fracture aperture and openness, but such indications should be confirmed with other data (e.g., flow logs). Image logs also provide information on lithologic features that help confirm lithologic and HGU assignments. 


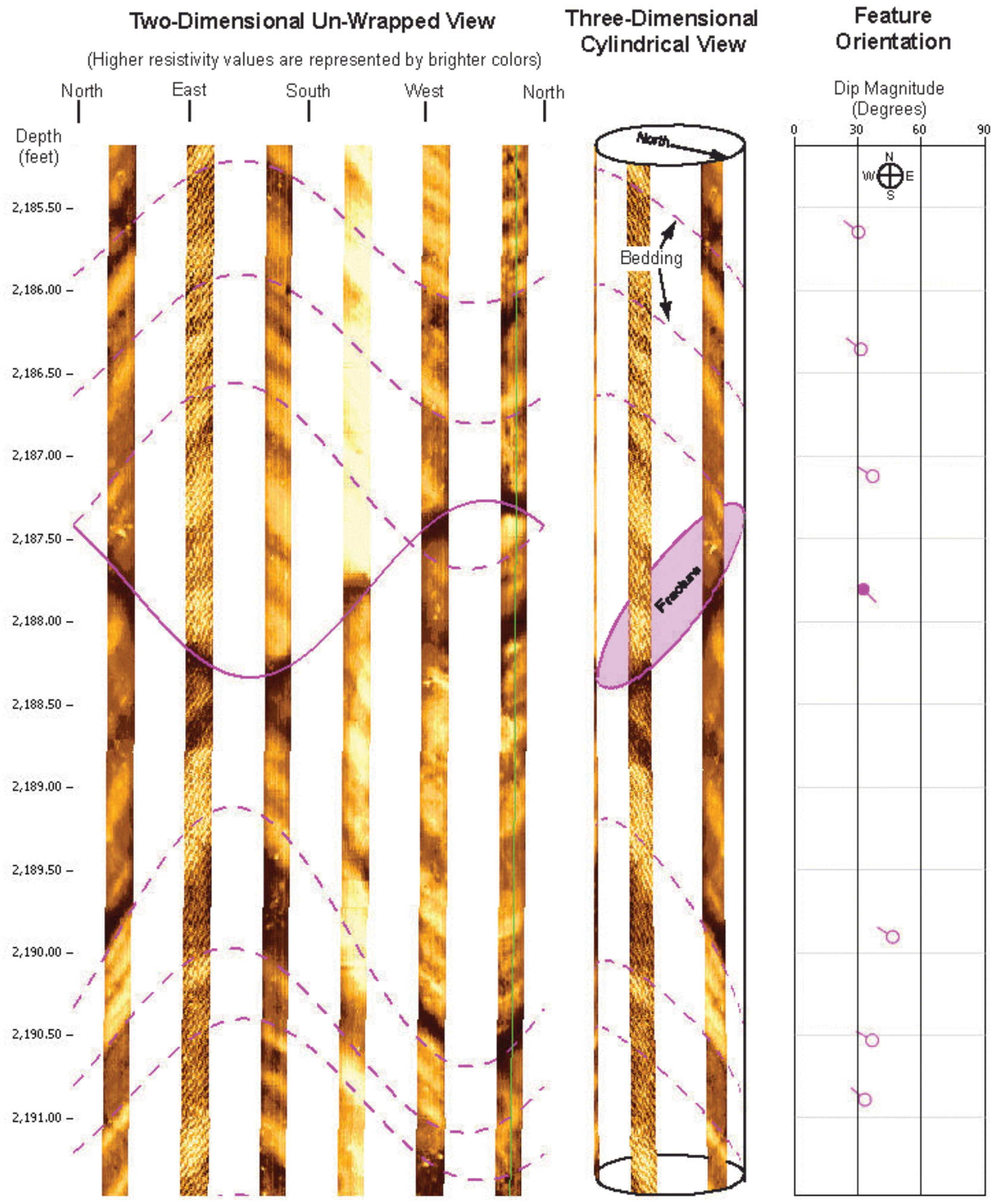

Figure 2-4

A Portion of the Borehole Image Log from UGTA Well ER-16-1 Showing a Fracture Within Highly Bedded Shale 
The visual nature of image logs and the power of image log interpretation software may give a false sense of confidence to interpreters of borehole image data. Like all log data, image logs have unique advantages as well as limitations, and should not be interpreted exclusive of other $\log$ and geologic data. 


\subsection{Examples of Geophysical Log Responses in NTS HGUs}

Geophysical logs are an important part of the arsenal of tools available for hydrogeologic characterization of UGTA wells. These tools also typically include geological logs developed from descriptions of samples from boreholes, petrographic, mineralogic, chemical, and biostratigraphic analyses on these samples, and drilling characteristics. Ultimately, data from a borehole are integrated with data from other nearby boreholes and surface geologic exposures to produce a detailed geologic and hydrogeologic interpretation for the borehole site.

Consequently, the interpretations included in the examples shown in this report are based on a variety of data and not just the geophysical logs discussed here.

\subsection{Welded-Tuff Aquifer in Well ER-5-4 \#2}

Ash-flow tuffs are noteworthy lithologic units at the NTS. These volcanic deposits are the result of large pyroclastic eruptions, and are commonly associated with caldera formation at the NTS (Byers et al., 1976). These common and widespread volcanic units form important aquifers where they have become welded due to compaction of the still-hot and semi-molten interiors as the ash-flow cools. The resulting hard and dense rocks form WTAs, characterized by relatively low primary matrix porosity and permeability but high fracture permeability (Winograd and Thordarson, 1975).

UGTA Well ER-5-4 \#2, drilled in the central portion of Frenchman Flat as part of the Frenchman Flat Phase 2 drilling activities, encountered two WTAs at the top of the volcanic section directly below the alluvium (NNSA/NSO, 2005a). The uppermost WTA, penetrated from 1,120.4 to 1,185.7 meters (m) (3,676 to 3,890 feet [ft]), shows a particularly nice welding profile and, thus, provides a good opportunity to observe geophysical log responses within a WTA. This uppermost WTA consists of welded ash-flow tuff assigned to the Ammonia Tanks Tuff, which was erupted 11.45 million years ago from the Timber Mountain caldera complex (Sawyer et al., 1994), located approximately 40 kilometers (km) (25 miles [mi]) northwest of Frenchman Flat. The WTA is clearly distinguished on the resistivity log from Well ER-5-4 \#2 as an interval of higher resistivity relative to the overlying and underlying units that consist of AA and VTA, respectively (Figure 3-1). The higher resistivity is mainly the result of the reduction in matrix porosity that occurs during the welding process. Resistivity values are observed to increase towards the central portion of the WTA as the degree of welding increases. Resistivity values are more than an order of magnitude greater in the moderately welded interior of the WTA than values in the nonwelded and more porous base of the ash-flow tuff. The resistivity log also 


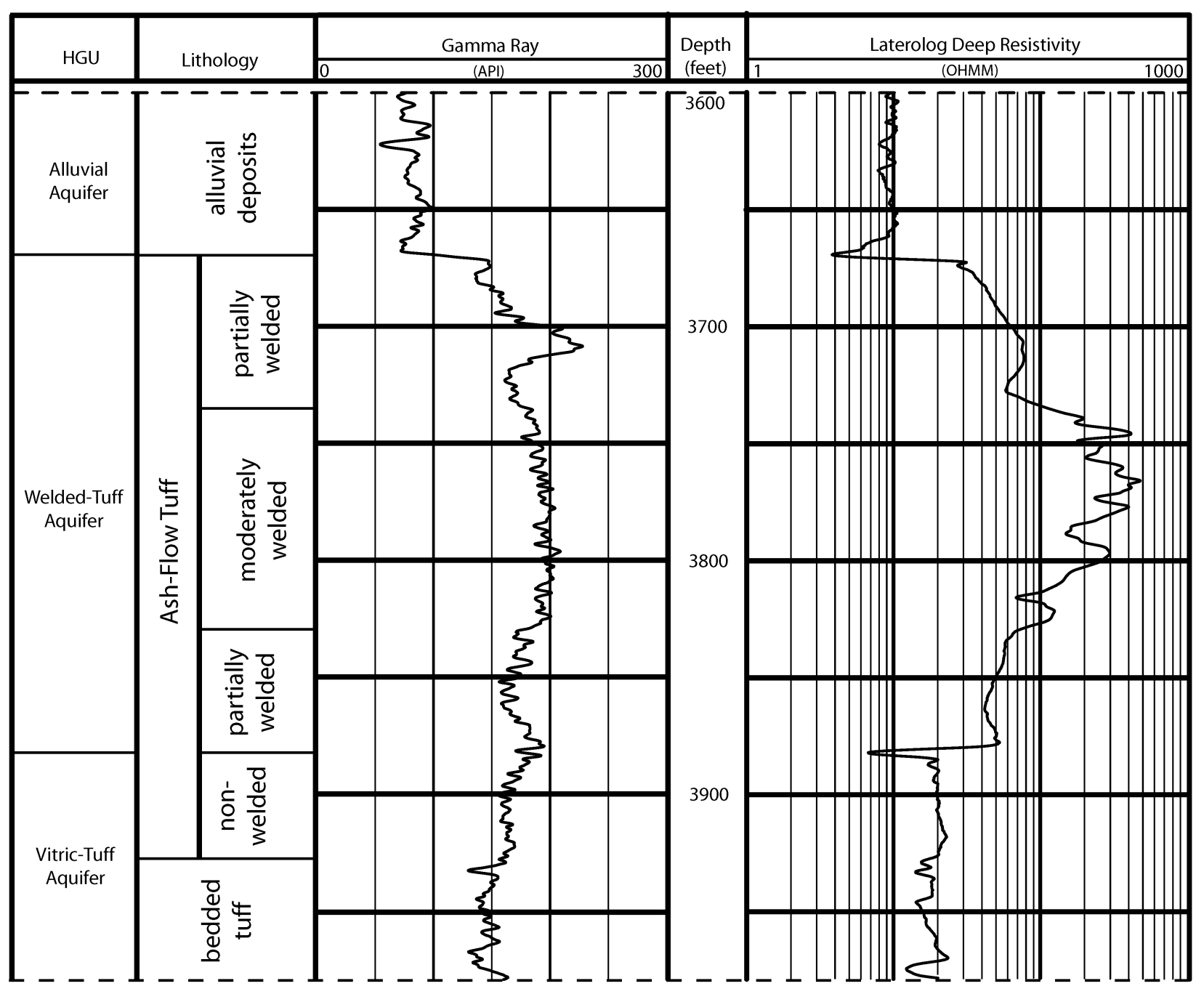

Figure 3-1

Portions of the Gamma-Ray and Resistivity Logs for Well ER-5-4 \#2 
indicates that the upper nonwelded zone has been eroded off at this location, which resulted in alluvium being deposited directly on top of the WTA. The WTA is also indicated on the gamma-ray log as an interval of higher natural radioactivity (Figure 3-1). The contact between AA and underlying WTA is quite evident on both logs as a conspicuously abrupt increase in resistivity and natural radioactivity and, thus, allows for a precise and confident determination of the contact between the two HGUs.

Figure 3-2 shows the neutron- and density-derived porosity curves for the upper WTA in Well ER-5-4 \#2. Because the porosity values are calculated using limestone matrix values, values read directly off the logs are not valid for WTA. General relationships of the porosity curves, however, are valid and useful in confirming hydrogeologic interpretations. As would be expected, both logs show a substantial decrease in porosity towards the center of the WTA, corresponding to an increase in welding. Both the overlying AA and underlying VTA show considerably higher porosity values than the WTA.

\subsection{Tuff Confining Units and Welded-Tuff Aquifer in Well ER-EC-1}

UGTA Well ER-EC-1 was drilled in 1999 approximately $4 \mathrm{~km}$ (2.5 mi) southwest of Area 20 on the southern edge of Pahute Mesa (U.S. Department of Energy, Nevada Operations Office, 2000). The well was drilled to a total depth of $1,524.0 \mathrm{~m}$ (5,000 ft) and penetrated a diverse assemblage of volcanic HGUs, including VTAs, WTAs, LFAs, and TCUs. Between the depths of 914.4 and 1,219.2 $\mathrm{m}$ (3,000 and 4,000 ft), the well penetrated two intervals of TCU separated by a WTA, and so provides an excellent opportunity to compare geophysical log signatures between these two important volcanic HGUs.

WTA is clearly delineated on the resistivity log in Figure 3-3. Between the depths of 1,036.3 and 1,066.8 $\mathrm{m}$ (3,400 and 3,500 ft), the WTA shows resistivity values more than an order of magnitude greater than the overlying and underlying TCU. This is consistent with the considerable reduction of matrix porosity that occurs during the welding process. The log also indicates that welding increases rapidly, particularly at the top of the unit. Like resistivity, gamma-ray values are also typically higher in WTAs than in TCUs.

The resistivity log also reveals details of the TCU intervals. The log distinguishes quite well between bedded tuff and more homogeneous deposits of nonwelded tuff. As one might expect, bedded tuff typically has a more jagged log signature than the more homogeneous deposits of

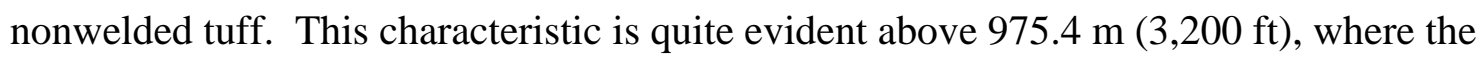
relatively low but jagged resistivity signature is typical of zeolitic bedded tuff. From 975.4 to 


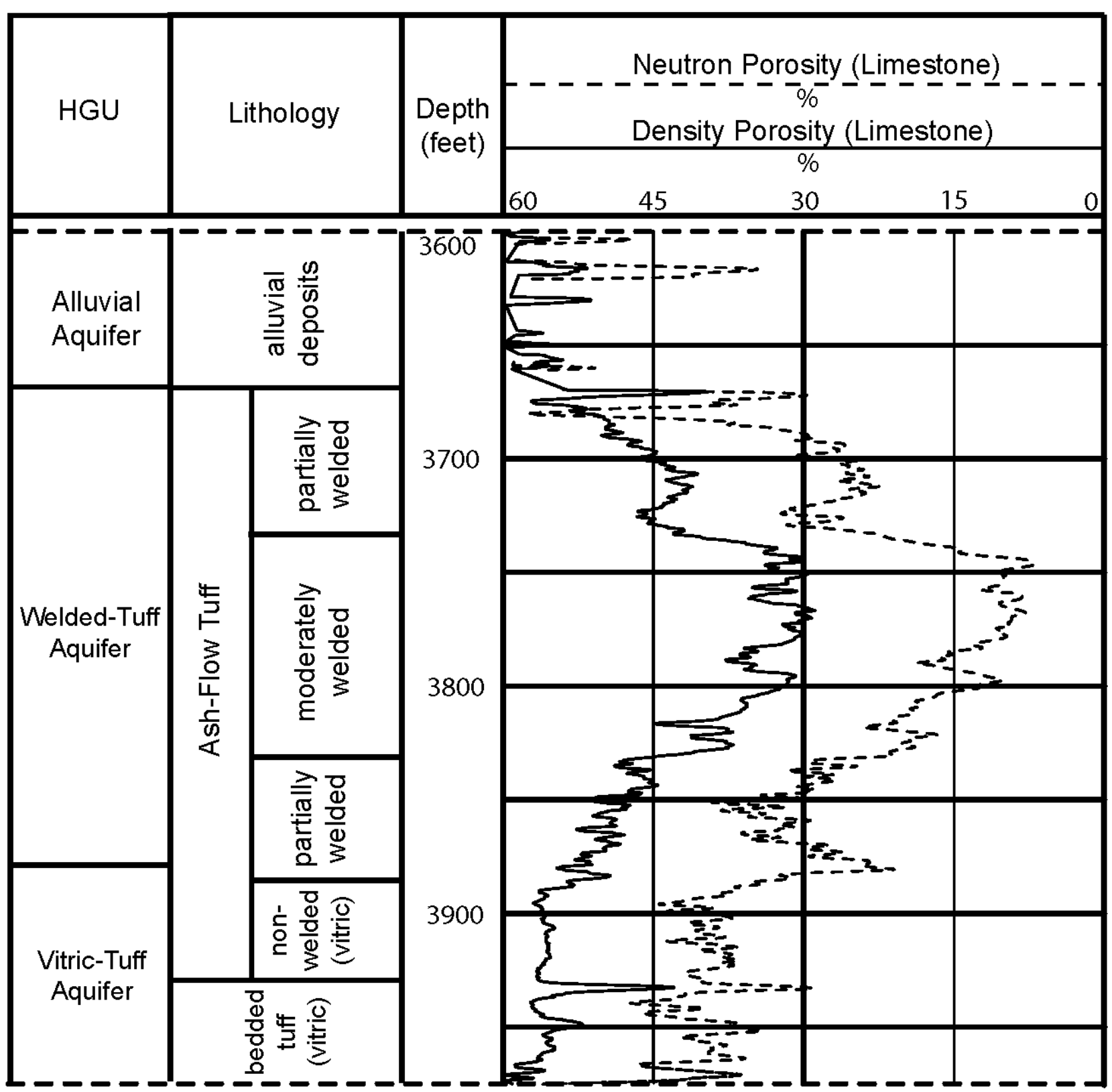

Figure 3-2

Portions of the Neutron- and Density-Derived Porosity Logs for Well ER-5-4 \#2 


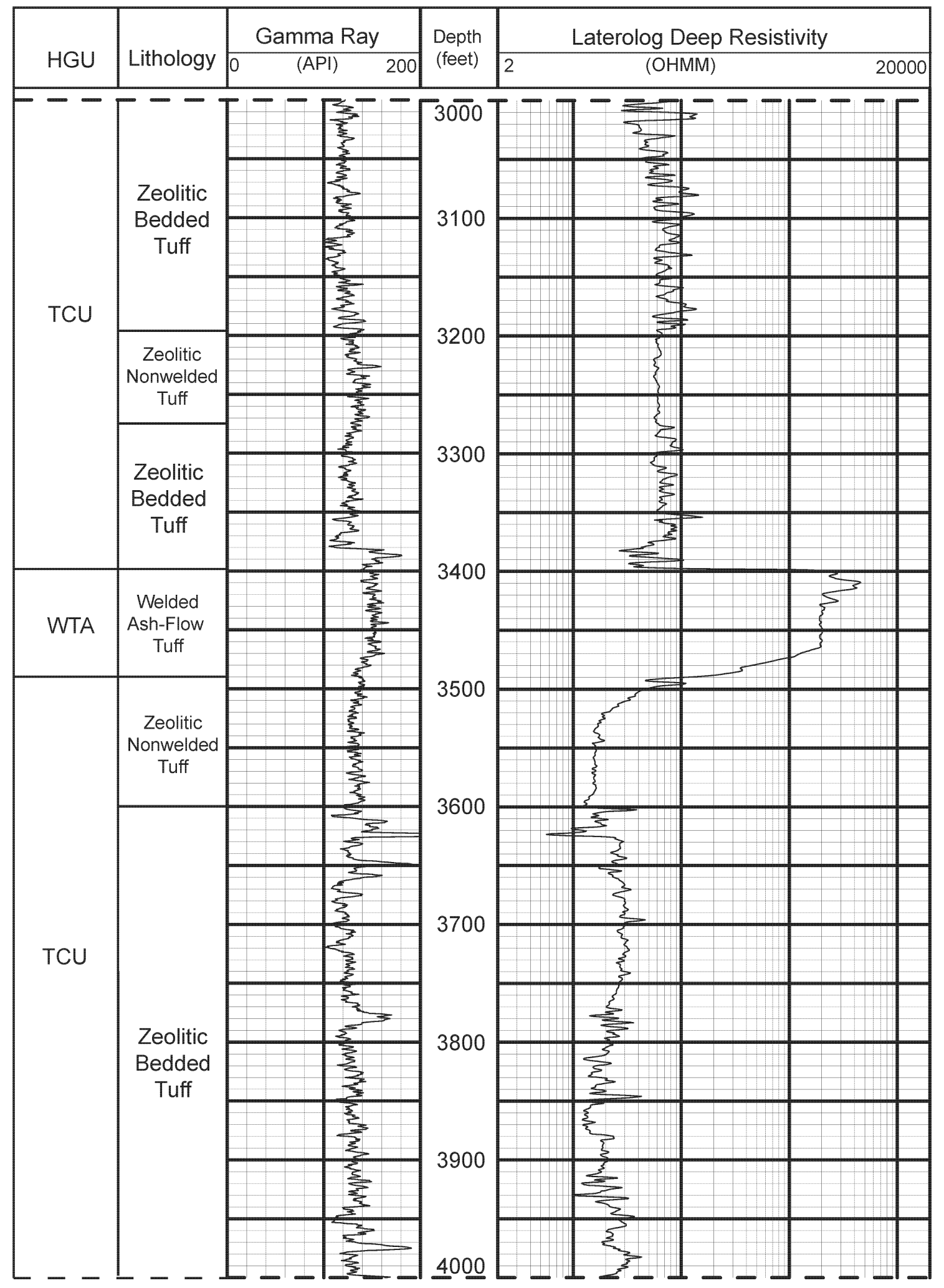

Figure 3-3

Portions of the Resistivity and Gamma-Ray Logs from Well ER-EC-1 
$998.2 \mathrm{~m}$ (3,200 to 3,275 ft), the resistivity curve is much smoother, indicating a general lack of bedding within this interval. The resistivity curve is again smooth from 1,066.8 to 1,097.3 m (3,500 to 3,600 ft) and likely represents the nonwelded basal portion of the overlying welded ash-flow tuff.

Other geophysical logs also delineate quite well the difference between the two HGUs. Figure 3-4 shows the sonic, epithermal neutron, and density logs for the same interval in Well ER-EC-1. The WTA is apparent in all three logs. The higher density and corresponding decrease in porosity results in faster acoustic travel times, higher epithermal neutron counts, and higher bulk density than the adjacent and higher porosity TCU intervals.

\subsection{Vitric-Tuff Aquifer and Tuff Confining Unit in Well ER-2-1}

The VTA and TCU are composed of the same volcanic lithologies, typically bedded sequences of nonwelded ash-flow tuff and ash- and pumice-fall deposits, although the pumiceous portions of lava flows are also included. What distinguishes these two HGUs is the presence or absence of post-depositional alteration, particularly zeolitization.

This section shows an example from UGTA Well ER-2-1 of the use of the borehole image and density logs to evaluate the lithologic character of VTA and TCU and, thus, add confidence to geologic interpretations and HGU determinations. Well ER-2-1 was drilled in 2003 in northcentral Yucca Flat (NNSA/NSO, 2004a). The well was drilled to a total depth of $792.5 \mathrm{~m}$

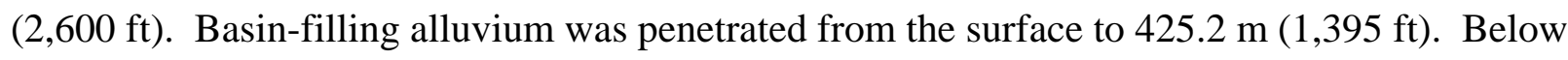

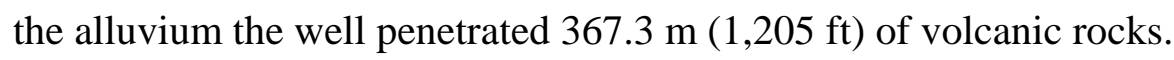

Figure 3-5 shows a portion of Well ER-2-1, including the borehole image (i.e., Haliburton's Electric Micro Imager ${ }^{\circledR} \log$ ) and density logs, as well as the corresponding interpreted lithologic units and HGUs. A conspicuous change in the character of the borehole image log is observed at approximately $579.1 \mathrm{~m}$ (1,900 ft). Horizontal striping below $579.1 \mathrm{~m}$ (1,900 ft) indicates lowangle planar features cutting the borehole. These planar features are bed contacts within a

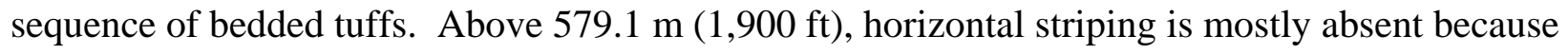
the interval is massive nonwelded ash-flow tuff that forms the base of the Rainier Mesa Tuff.

The density log in Figure 3-5 also indicates massive nonwelded tuff overlying bedded tuff. The relatively low density and smooth signature of the log above $579.1 \mathrm{~m}(1,900 \mathrm{ft})$ is consistent with

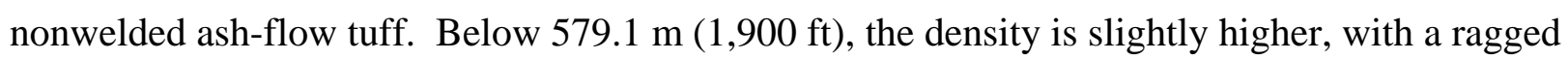
character consistent with bedded tuff. Although the transition from vitric to zeolitic bedded tuff 


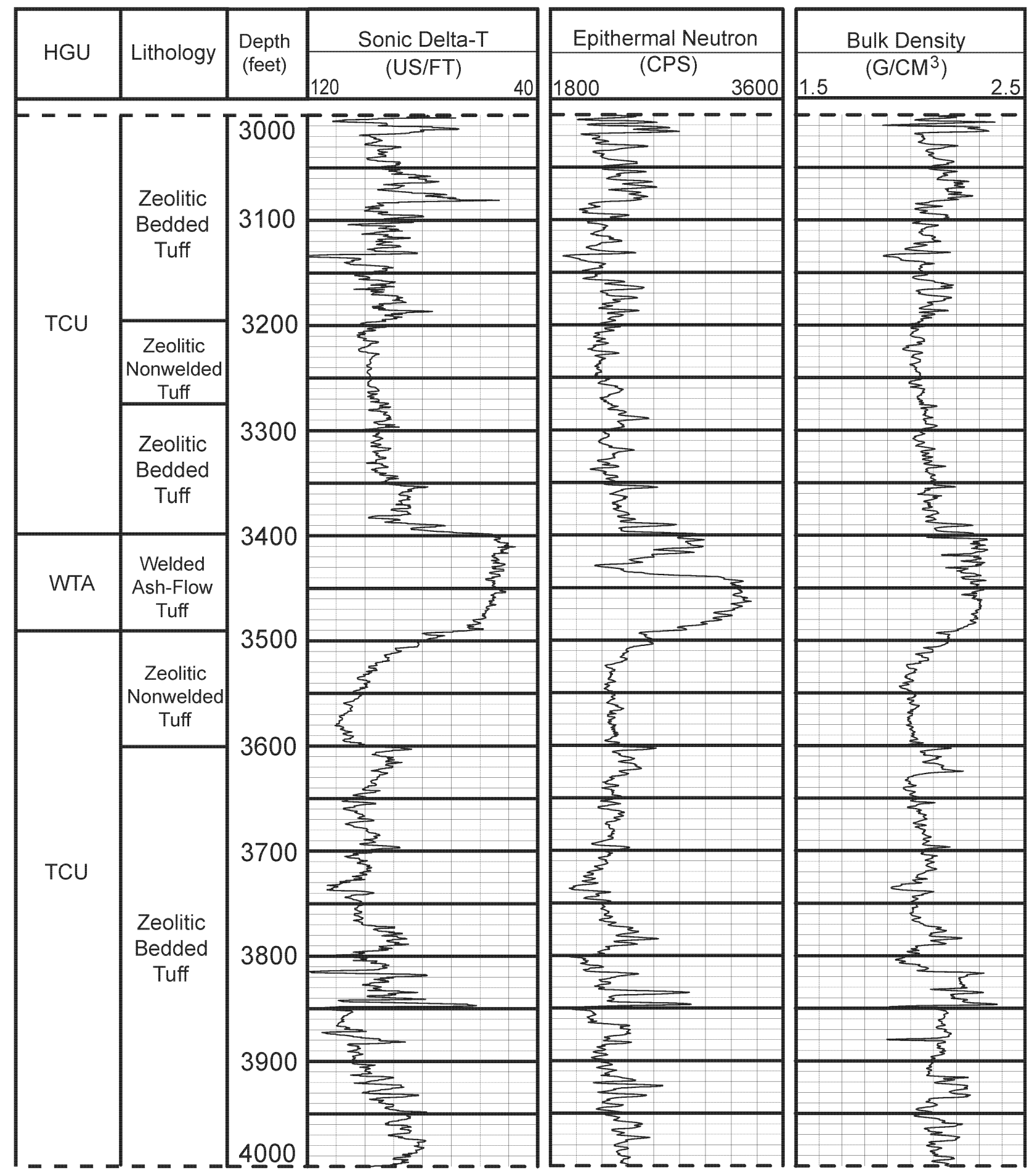

Figure 3-4

Portions of the Sonic, Neutron, and Density Logs from Well ER-EC-1 


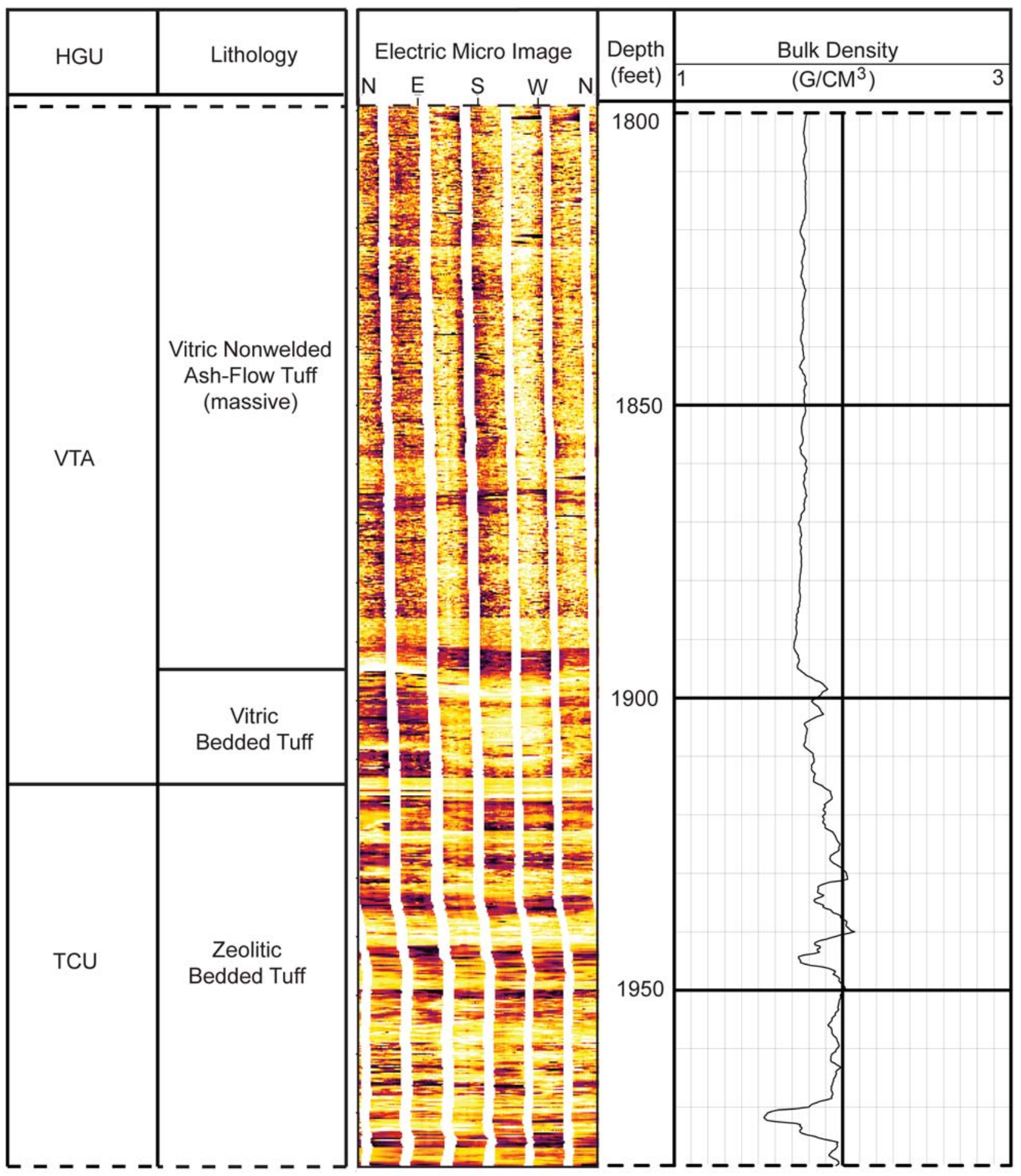

Figure 3-5

Portions of the Borehole Image and Density Logs from Well ER-2-1 
at approximately $583.7 \mathrm{~m}(1,915 \mathrm{ft})$ is not indicated on the image log, it is seen on the density log as a slight increase in density. Analysis of the borehole image log using interpretation software indicates that bedding below $579.1 \mathrm{~m}$ (1,900 ft) dips from 12 to 17 degrees to the southwest, which is consistent with down-on-the-east movement along basin-forming normal faults beneath Yucca Flat. Analysis of the image log also shows that the contact between the nonwelded ash-flow tuff and bedded tuff dips 75 degrees to the southwest, indicating that the ash-flow tuff was deposited on an erosional surface.

Figure 3-6 is a photograph of an exposure of the lower portion of Rainier Mesa Tuff on Pahute Mesa. The exposed section in the photograph is the same basic section drilled in Well ER-2-1, and provides direct observation and comparison of the characteristics observed in the borehole image and density logs of the well.

\subsection{Lava-Flow Aquifer and Tuff Confining Units in Well ER-20-5 \#3}

Rhyolitic lava flows are common and hydrologically important geologic units beneath Pahute Mesa. Individual flows typically have complex internal distributions of lithofacies with significantly different flow properties (i.e., HGUs). Lithofacies include pumiceous and perlitic zones, stony lava, vitrophyre, and flow breccia. Lithofacies can be vitric, devitrified, silicic, or zeolitic. In addition, flows commonly coalesce and overlap, forming thick intervals with complex distributions of HGUs. Consequently, the accurate geologic characterization of lava flows is critical for properly assigning HGUs to the various lithofacies within intervals of rhyolitic lava.

UGTA Well ER-20-5 \#3 was drilled near the southwestern edge of Pahute Mesa in Area 20. Drill cuttings indicated that rhyolitic lava was penetrated from 979.0 to $1,189.3 \mathrm{~m}(3,212$ to 3,902 ft) within the mafic-poor Calico Hills Formation. The cuttings also suggested the interval contains a complex distribution of lithofacies, including zeolitic pumiceous lava; devitrified, flow banded, and stony lava; and vitrophyre. Because of the 3.0-m (10-ft) sample interval and the mixing of cuttings during the drilling process, it was difficult to determine the proper distribution of lithofacies, and consequently HGUs, within the interval. The geophysical logs, however, helped considerably in the characterization of this interval (Figures 3-7 and 3-8).

Drill cuttings indicated that zeolitic pumiceous lava is present at the top and particularly the bottom of the flow. Although expressed in the cuttings, the thinner upper pumiceous lithofacies is not particularly apparent in the geophysical logs. The lower pumiceous zone, however, is clearly seen in the logs. It is quite apparent on the resistivity log as a zone of low resistivity with a conspicuously smooth curve on the deep laterolog from 1,114.0 to 1,188.7 m (3,655 to 


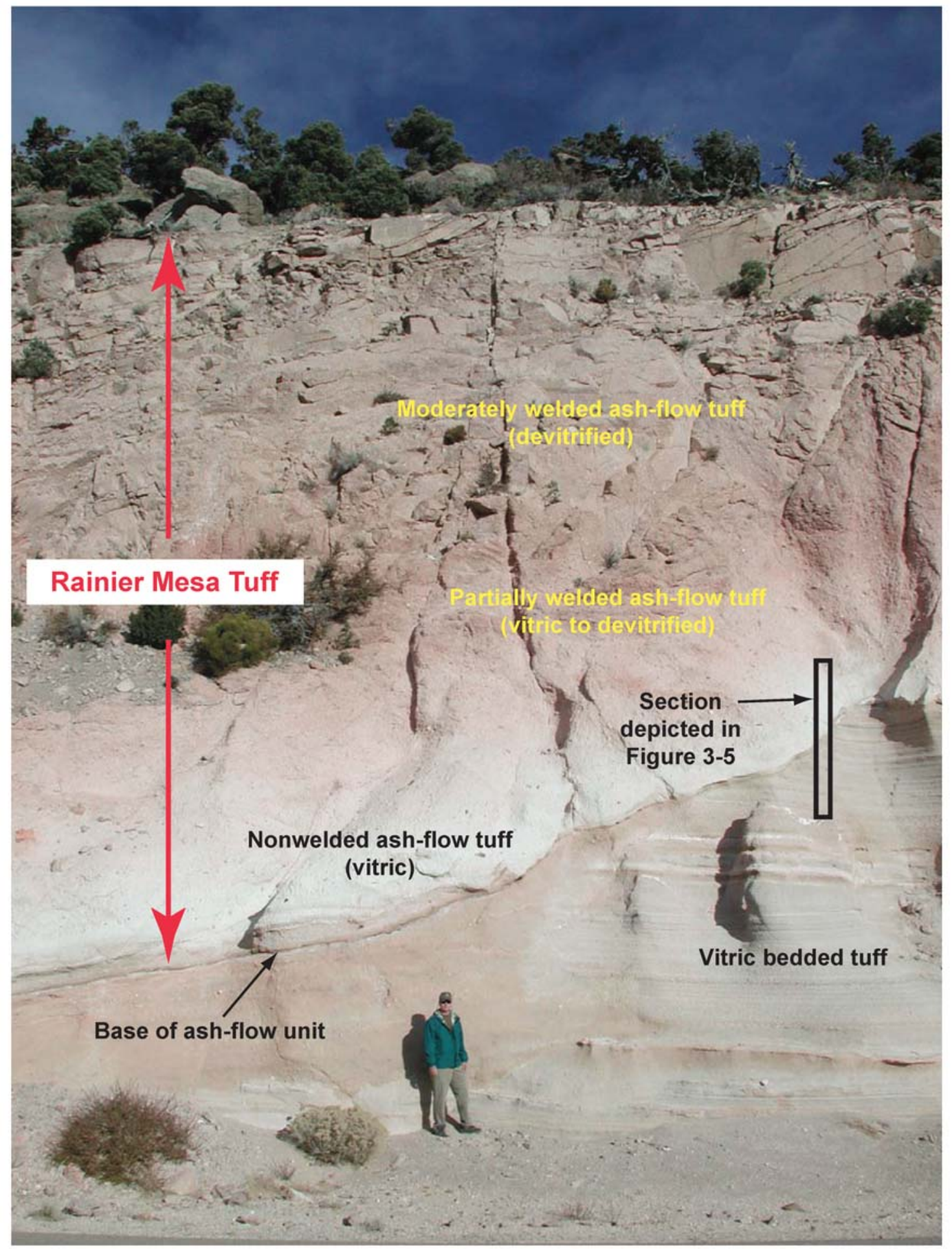

Figure 3-6

Exposure of the Lower Portion of the Rainier Mesa Tuff in Area 19 of the NTS

Showing a Geologic Section Similar to that Logged in Well ER-2-1 and Depicted in Figure 3-5

(Note: None of the units in photograph are zeolitized at this location, unlike the section in Well ER-2-1.) 


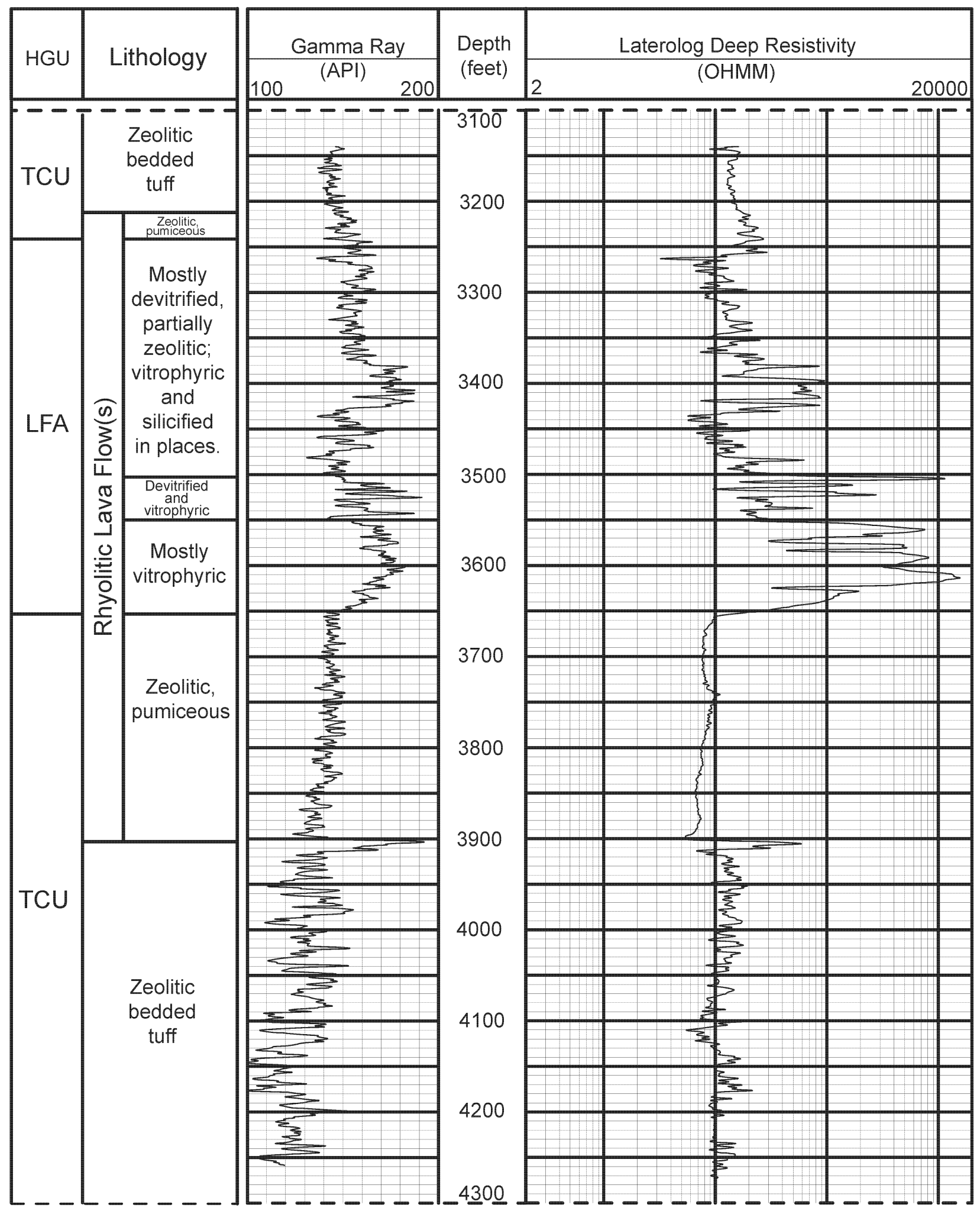

Figure 3-7

Portions of the Gamma-Ray and Deep Laterolog from Well ER-20-5 \#3 


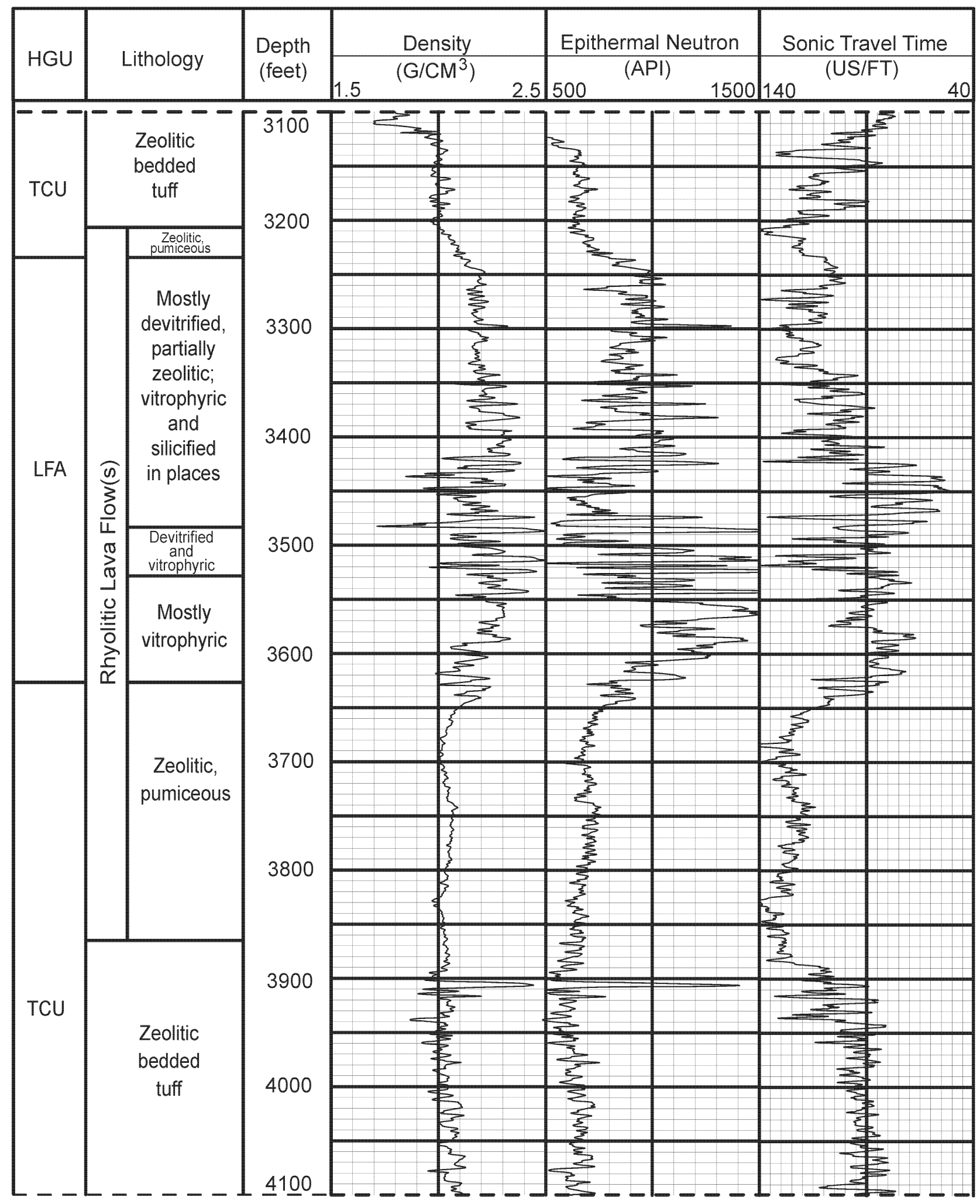

Figure 3-8

Portions of the Density, Neutron, and Sonic Logs from Well ER-20-5 \#3 
3,900 ft) (Figure 3-7), consistent with poorly bedded zeolitic volcanic rocks. The lower pumiceous zone is also readily apparent on other logs (Figure 3-8). The interval's lower natural radioactivity, resistivity, density, and neutron values and slower acoustic travel times contrast quite conspicuously with those of the overlying lava flow lithofacies, which include vitrophyre and devitrified stony lava according to the drill cuttings. The pumiceous interval also can be easily distinguished from the underlying zeolitic bedded tuff, particularly on the resistivity, density, and sonic logs. The geophysical log characteristics of the lower pumiceous interval allowed for confident and precise establishment of the interval as TCU.

Drill cuttings indicated that the interval between the upper and lower pumiceous zones consists of a particularly complex distribution of various lava-flow lithofacies and associated alteration, and the geophysical log signatures reflect this variability. All logs show a wide range of values through the interval, indicating considerably different geophysical properties that likely correspond to different hydrologic properties and, thus, different HGUs. Most of the interval, however, shows geophysical log values different than the zeoliltic intervals and consistent with lower porosity and denser rocks such as vitrophyre and devitrified lava. Consequently, the interval was assigned as LFA based mainly on the geophysical logs that show that the majority of the interval is made up of units with properties consistent with LFA.

\subsection{Carbonate Aquifer in Well ER-12-3}

UGTA Well ER-12-3 was drilled in 2005 to help characterize the hydrogeology of the central portion of Rainier Mesa in the vicinity of the N-Tunnel complex (NNSA/NSO, 2006). The well

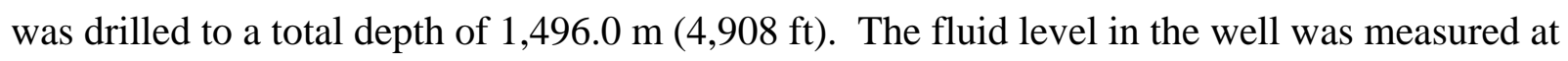
$949.1 \mathrm{~m}$ (3,113.7 ft) on June 11, 2005. The well penetrated $673.6 \mathrm{~m}$ (2,210 ft) of Tertiary volcanic rocks consisting mostly of TCU, with lesser amounts of VTA and WTA. At $673.6 \mathrm{~m}$ (2,210 ft), the well encountered CA consisting of Paleozoic dolomite. The well remained in CA to total depth at $1,496.0 \mathrm{~m}(4,908 \mathrm{ft})$.

Drill cuttings samples indicated a lithologic change from dolomite to limestone within the CA at around 1,249.7 $\mathrm{m}(4,100 \mathrm{ft})$. Analysis of the geophysical logs clearly shows an abrupt change from dolomite (above) to limestone (below) at 1,250.3 m (4,102 ft). This is best seen on the combination neutron-density log, which is an excellent lithologic indicator in sedimentary rocks. Figure 3-9 shows a portion of the neutron-density log from Well ER-12-3. The two curves displayed on the far right represent porosity values calculated from the density and neutron tool readings, and calculated using limestone matrix values. A contact can clearly be seen near $1,249.7 \mathrm{~m}(4,100 \mathrm{ft})$. Above this depth the two curves form separate tracks, with the 


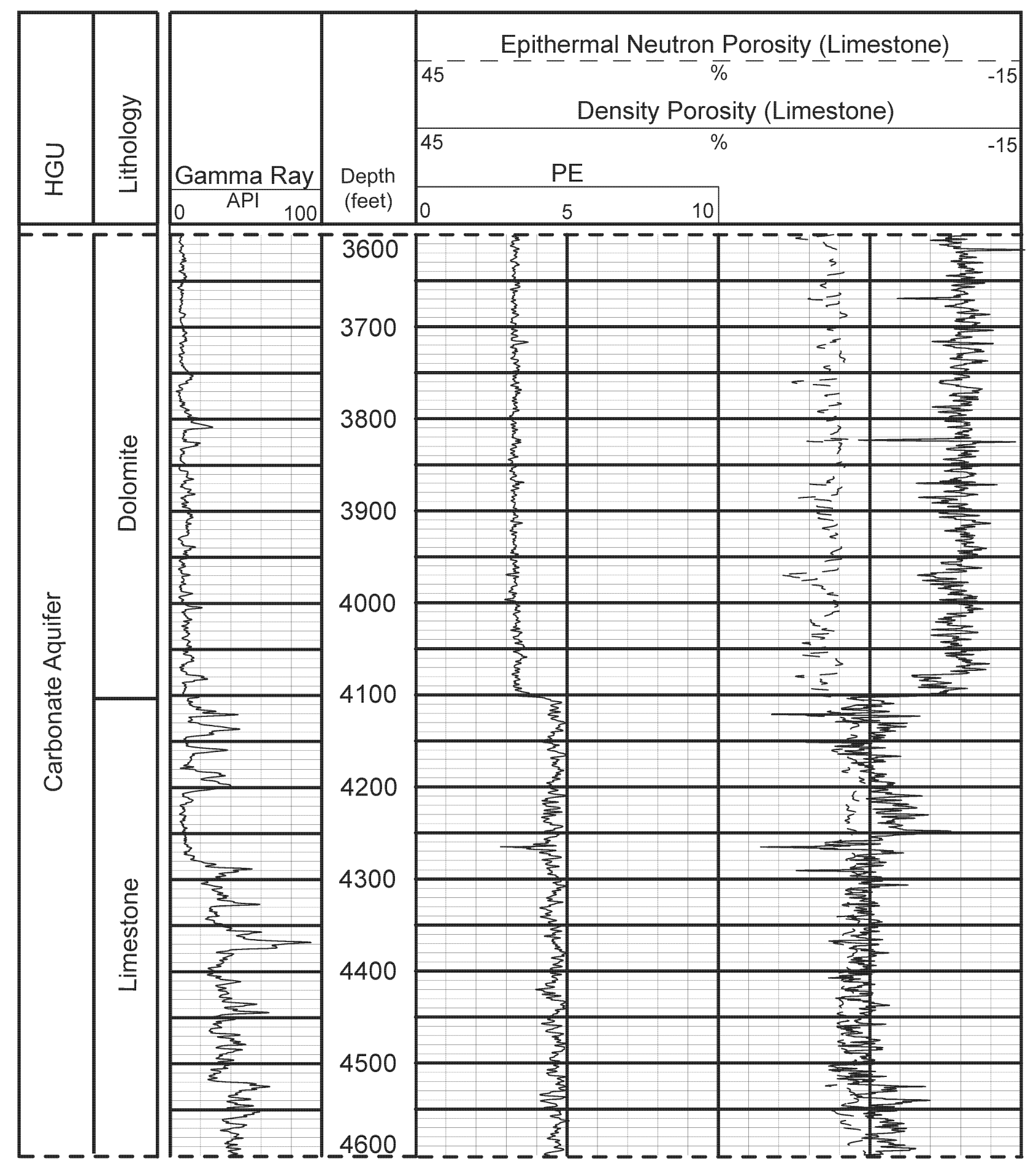

Figure 3-9

Portions of the Gamma-Ray and Combination Neutron-Density Logs From Well ER-12-3 
neutron-derived porosity curve showing higher porosity values than the density-derived curve. This is the typical character of neutron-density porosity curves in dolomite when porosity curves are calculated using limestone matrix values. Below 1,249.7 $\mathrm{m}(4,100 \mathrm{ft})$, the two curves track close together as would be expected in limestone. This lithologic change is also clearly seen in the PE curve. Above 1,249.7 m (4,100 ft), the PE curve shows consistent values near 3, which is typical of dolomite. Below this depth, the PE curve is near 5, a value typical of limestone.

Both sets of log curves show a very abrupt contact at precisely 1,250.3 m (4,102 ft). The abrupt nature of this contact as indicated by the geophysical logs suggests a fault contact, an interpretation supported by other stratigraphic and structural data (NNSA/NSO, 2006).

\subsection{Clastic Confining Unit in Well ER-12-2}

UGTA Well ER-12-2 was drilled in 2003 to help characterize the hydrogeology in the northwestern portion of Yucca Flat (NNSA/NSO, 2004b). The well was drilled to a total measured depth of 2,097.9 m (6,883 ft). After penetrating $186.0 \mathrm{~m}(610 \mathrm{ft})$ of alluvium and volcanic rocks, the well encountered CCU consisting of Mississippian shale. The well penetrated 1,912.0 m (6,273 ft) of CCU consisting predominantly of Mississippian shale and argillite with lesser amounts of sandstone, quartzite, and bioclastic limestone. Drill cuttings samples indicated that considerable amounts of sandstone and quartzite were penetrated by the well below 1,645.9 m (5,400 ft). However, the nature of these coarser grained units, particularly their quantity, distribution, and stratigraphic position, was difficult to ascertain from the drill cuttings samples due to the 3.0-m (10-ft) sample interval and mixing of lithologies during drilling. Fortunately, the geophysical logs, particularly the natural gamma-ray log, coupled with the drill cuttings samples, provide precise information on the lithologic character of the CCU below 1,645.9 m (5,400 ft). In Figure 3-10, the gamma-ray log clearly shows that the CCU in the lower portion of Well ER-12-2 consists of two thick intervals of quartzite and sandstone, with each overlain by intervals of interbedded shale, quartzite, and sandstone. As is typical for clastic sedimentary rocks, sandstones and quartzites show much less natural gamma-ray energy than the finer-grained shales (Merkel, 1983).

\subsection{Contact Between Tuff Confining Unit and Carbonate Aquifer in Well ER-5-3 \#2}

The contact between the volcanic rocks and underlying Paleozoic rocks is an interesting and important geologic contact at the NTS, and a much anticipated hydrogeologic contact during UGTA drilling operations that penetrate into the Paleozoic rocks. The contact is a major unconformity that typically represents more than 200 million years of “missing” geologic 


\begin{tabular}{|c|c|c|c|c|}
\hline \multirow[t]{2}{*}{ HGU } & \multirow[t]{2}{*}{ Lithology } & \multirow{2}{*}{$\begin{array}{c}\text { Depth } \\
\text { (feet) }\end{array}$} & \multicolumn{2}{|c|}{ Gamma Ray } \\
\hline & & & 0 & 200 \\
\hline--- & ------ & -- & $-\frac{-3}{3}$ & \\
\hline \multirow{27}{*}{$\begin{array}{l}\text { Clastic } \\
\text { Confining } \\
\text { Unit }\end{array}$} & \multirow{6}{*}{ Shale } & 5100 & & \\
\hline & & \multirow{2}{*}{5200} & 3 & 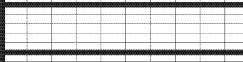 \\
\hline & & & $\frac{z}{3}$ & \\
\hline & & 5300 & $\frac{2}{2}$ & \\
\hline & & \multirow{2}{*}{5400} & $\frac{5}{3}$ & \\
\hline & & & $\frac{2}{2}$ & $\bar{E}$ \\
\hline & \multirow{6}{*}{$\begin{array}{c}\text { Interbedded } \\
\text { Shale, Quartzite, } \\
\text { and Sandstone }\end{array}$} & 5500 & $\equiv$ & \\
\hline & & \multirow{2}{*}{5600} & 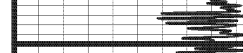 & \\
\hline & & & $=$ & 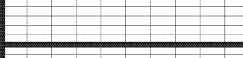 \\
\hline & & 5700 & 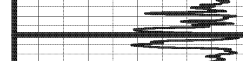 & \\
\hline & & \multirow{2}{*}{5800} & 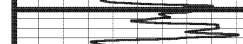 & \\
\hline & & & 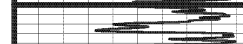 & \\
\hline & \multirow{4}{*}{ Quartzite } & 5900 & $z$ & \\
\hline & & 6000 & $\frac{z}{2}$ & \\
\hline & & \multirow{2}{*}{6100} & 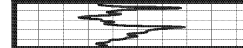 & \\
\hline & & & 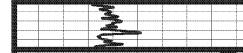 & \\
\hline & \multirow{5}{*}{$\begin{array}{c}\text { Interbedded } \\
\text { Shale, Quartzite, } \\
\text { and Sandstone }\end{array}$} & \multirow{3}{*}{$\begin{array}{l}6200 \\
6300\end{array}$} & $=3$ & \\
\hline & & & & \\
\hline & & & $\Longrightarrow$ & $E$ \\
\hline & & \multirow{2}{*}{$\begin{array}{l}6400 \\
6500\end{array}$} & $\underline{3}$ & $E$ \\
\hline & & & $\Longrightarrow$ & E \\
\hline & & & $=$ & \\
\hline & & 6600 & 柆 & \\
\hline & Quartzite & 6700 & 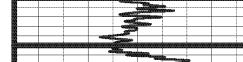 & \\
\hline & Sandstone & & $\frac{3}{8}$ & \\
\hline & & 6800 & $\sqrt{\frac{3}{3}}$ & \\
\hline & & & & \\
\hline
\end{tabular}

Figure 3-10

Bottom Portion of the Gamma-Ray Log from Well ER-12-2 
history. At many places at the NTS, it also represents the contact between the younger TCU and the regional carbonate aquifer (Figure 3-11). The dramatic differences in the formative geologic processes and original depositional environments for these two HGUs lead to significant differences in physical and mineralogical properties that make the contact between these two HGUs easy to recognize and precisely determine on geophysical logs.

The TCU at the NTS consists mostly of nonwelded ash-flow tuff and bedded ash- and pumicefall volcanic deposits erupted between approximately 9 and 15 million years ago from various sources within the southwestern Nevada volcanic field (Sawyer et al., 1994) and deposited as a thick blanket of originally vitric material across an eroded pre-volcanic landscape (Byers et al., 1976). Subsequent post-depositional processes have altered the original glassy constituents of many of these volcanic deposits to zeolitic, argillic, and quartzo-feldspathic mineral assemblages, resulting in relatively low density, high porosity rocks with low permeability.

In contrast, Paleozoic carbonate rocks that compose most of the CA were chemically precipitated in marine depositional environments between approximately 200 and 500 million years ago (Slate et al., 1999). These rocks now consist mostly of high density, low porosity limestone and dolomite with low effective porosity but locally high fracture permeability. The contact between the TCU and CA at the NTS is typically sharp and abrupt, reflecting the dramatic differences in the two units and the unconformable character of the contact.

An excellent example of the contact between the TCU and CA occurs in Well ER-5-3 \#2, located in the northern portion of Frenchman Flat. The well was drilled in 2000 to a total depth of 1,732.2 m (5,683 ft) (NNSA/NSO, 2005b). Well ER-5-3 \#2 was the deepest well in a three-well cluster designed to collect geologic and hydrologic data near a group of underground nuclear tests in northern Frenchman Flat. In descending order, the well penetrated $591.3 \mathrm{~m}$ (2,060 ft) of Quaternary and Tertiary alluvium, $798.0 \mathrm{~m}$ (2,618 ft) Tertiary volcanic rocks, and $306.3 \mathrm{~m}$ $(1,005 \mathrm{ft})$ of Paleozoic dolomite. A continuous interval of TCU consisting mostly of zeolitic

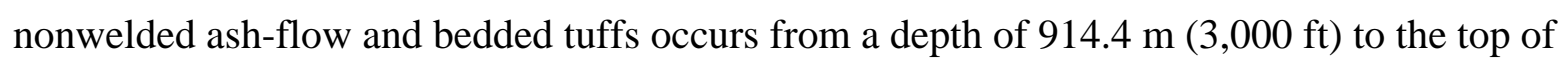
Paleozoic dolomite at 1,425.9 $\mathrm{m}(4,678 \mathrm{ft})$. Geologic and geophysical data suggest that the contact between the TCU and CA in Well ER-5-3 \#2 is a fault contact (NNSA/NSO, 2005b). Still, the comparisons of the geophysical log responses between the two HGUs, as discussed below, are valid; however, the abruptness of the contact may be enhanced by the fault.

The contact between the TCU and CA is clearly observed in the gamma-ray and resistivity logs presented in Figure 3-12. The abundance of potassium minerals in the form of feldspar 

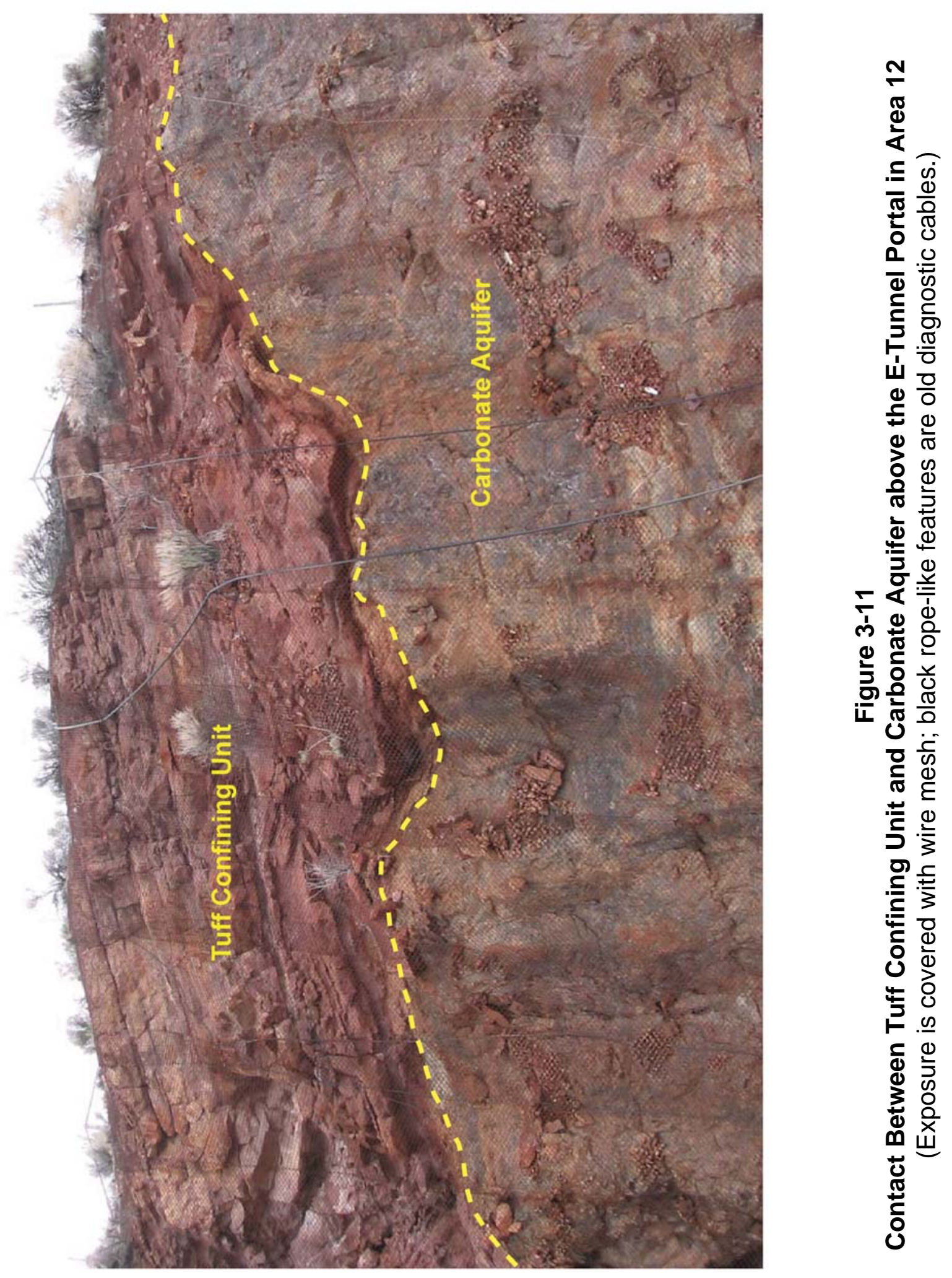


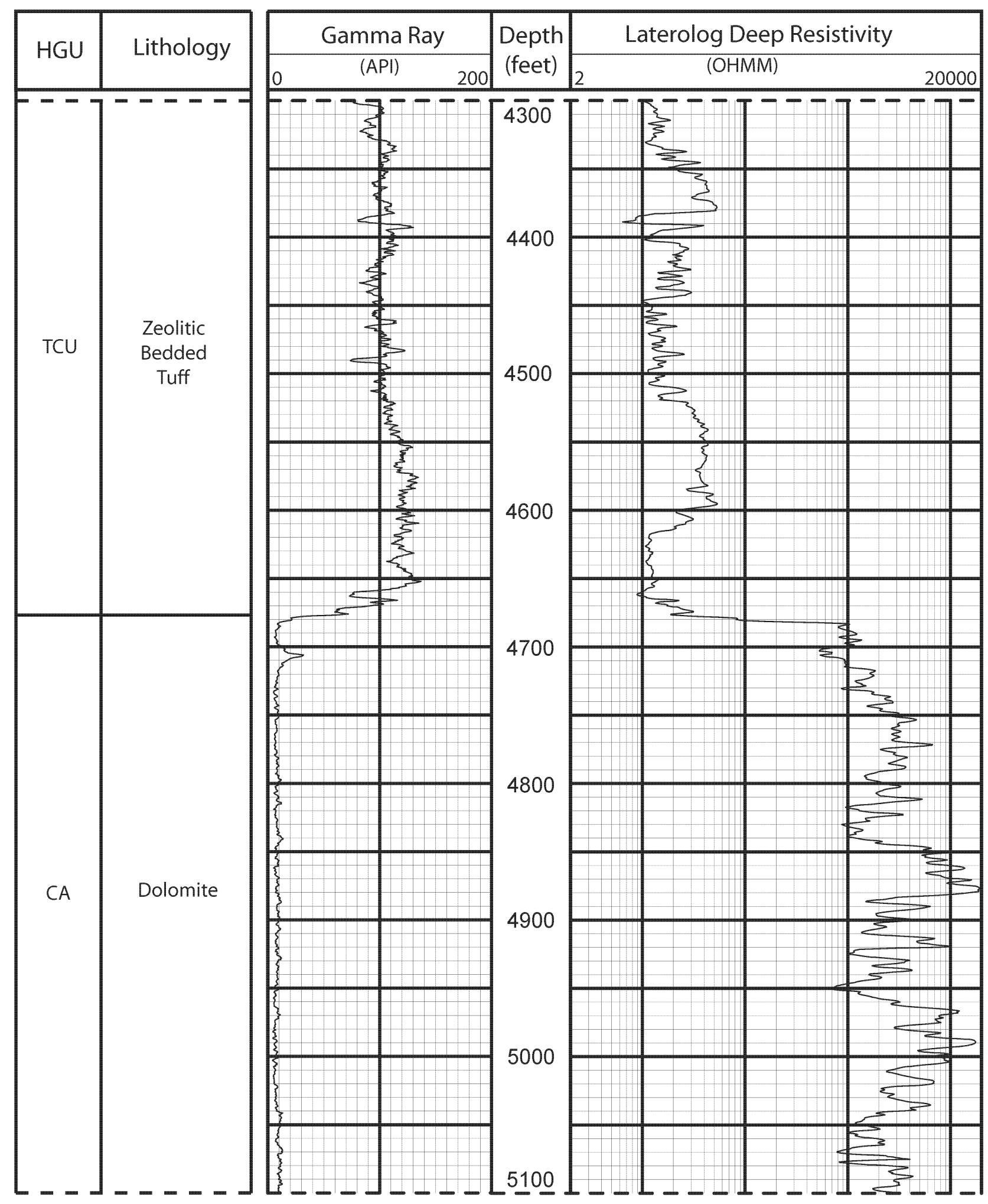

Figure 3-12

Portions of the Gamma-Ray and Laterolog from Well ER-5-3 \#2 
phenocrysts and biotite in volcanic rocks like those that compose the TCU result in relatively high proportions of naturally occurring radioactive minerals, particularly potassium- 40 . The presence of these minerals causes much higher natural gamma-ray readings than the much "cleaner" dolomite, which is composed almost entirely of dolomite and has very little or no potassium minerals. In Figure 3-12, the TCU shows gamma-ray values an order of magnitude greater than the underlying CA. The spiky character of the gamma-ray curve in the TCU reflects the variable concentrations of potassium in the individual tuff beds. The much smoother gamma-ray curve in the CA reflects the consistently very low concentrations of potassium within the dolomite of the CA. The absence of higher gamma-ray intervals within the CA indicates that little interbedded shale is present within the CA because shale beds, which contain higher concentrations of potassium minerals, would be visible as conspicuous increases in gamma-ray values within the CA interval.

The contact between TCU and CA is also conspicuous on the resistivity log in Figure 3-12. The low porosity CA shows resistivity values two orders of magnitude greater than the much more porous TCU. The contact is very sharp and abrupt on the resistivity log, reflecting the large differences in resistivity of the two HGUs.

Figure 3-13 shows the epithermal neutron, density, and sonic log curves across the contact between TCU and CA in Well ER-5-3 \#2. The epithermal neutron and density curves are included in the same track and are presented as calculated porosity values based on limestone matrix. Although porosity values read directly from the log are not valid because the rocks are not limestone, general relationships are valid and useful. As expected, the TCU shows consistently higher porosity values than the CA, and the contact between the two units is sharp and abrupt. Within the CA interval, the two porosity curves track separately, with the neutron curve reading higher porosity. This is a typical response of the neutron- and density-porosity curves in dolomite when the porosity curves are calculated based on limestone matrix, and confirms the lithologic assignment of dolomite determined from drill cuttings.

The contact between TCU and CA is also quite evident in the sonic log presented in the far right track of Figure 3-13. As would be expected, the denser CA has acoustic travel times considerably higher than TCU.

In summary, the contact between TCU and CA is an important hydrogeologic contact at the NTS. Fortunately, this contact is easily recognized and can be precisely determined using geophysical logs. The conspicuous nature of the contact results from considerably different physical and mineralogical properties of the two HGUs. 


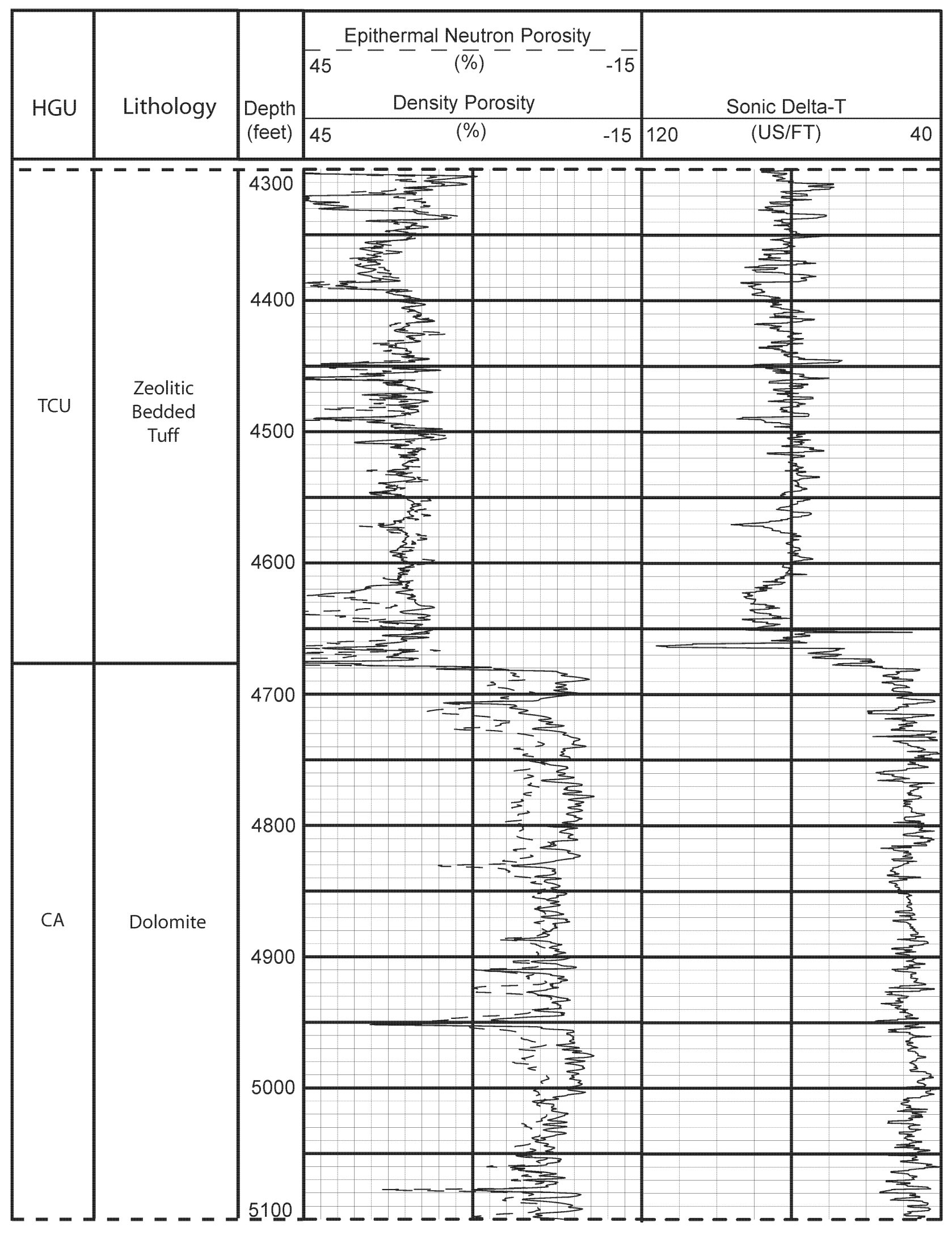

Figure 3-13

Portions of the Sonic and Combination Neutron-Density Logs from Well ER-5-3 \#2 


\subsection{Contact Between Alluvial Aquifer and Welded-Tuff Aquifer in Well ER-5-3}

Another important contact is that between volcanic rocks and overlying alluvial basin-filling deposits. This contact is typically referred to as the tuff-alluvium contact, and has been penetrated in numerous holes in Yucca Flat and Frenchman Flat. Hydrogeologically, the contact commonly demarcates AA from underlying volcanic aquifers and confining units (i.e., WTA, VTA, and TCU).

UGTA Well ER-5-3, drilled in the northern portion of Frenchman Flat, provides an excellent example of the tuff-alluvium contact. At the well location, alluvium directly overlies moderately welded ash-flow tuff assigned to the Ammonia Tanks Tuff (NNSA/NSO, 2005b), and thus, represents a contact between AA and WTA. The contact is sharp, abrupt, and conspicuous on geophysical logs, especially the gamma-ray log and laterolog (Figure 3-14). Based on the geophysical logs, the contact was picked at $622.4 \mathrm{~m}$ (2,042 ft) where the gamma-ray log and laterolog show abrupt increases in natural radioactivity and resistivity, respectively. As indicated by the gamma-ray log, natural radioactivity increases abruptly from approximately 100 API units in the alluvium to over 140 API units in the welded tuff. This reflects the generally lower natural radioactivity in sedimentary deposits than in volcanic deposits. Although tuffaceous and more radioactive than typical clastic sedimentary deposits, the alluvium is still less radioactive than volcanic deposits mainly because of a higher percentage of very low radioactive constituents such as quartz sand grains, and carbonate and quartzite clasts in the alluvium.

The contact between AA and WTA is also clearly seen on the laterolog. At $622.4 \mathrm{~m}(2,042 \mathrm{ft})$ resistivity values generally range from 20 to 80 OHMM and the resistivity curve has a serrated and spiky character, both typical of the more porous and highly bedded nature of alluvium. Below the depth of $622.4 \mathrm{~m}$ (2,042 ft), resistivity values increase abruptly to between 200 and 1,000 OHMM and the resistivity curve is smoother, reflecting the decrease in porosity and nonbedded nature of welded ash-flow tuff. The increase in resistivity towards the center of the WTA reflects the increase in welding and corresponding reduction in porosity typical of welded ash-flow tuffs.

\subsection{Correlating WTAs Between Wells ER-5-3 and ER-5-4 \#2}

Geophysical logs are powerful correlating tools, and are routinely used to correlate geologic units between drill holes and wells. Wells ER-5-3 and ER-5-4 \#2, drilled during the Frenchman 


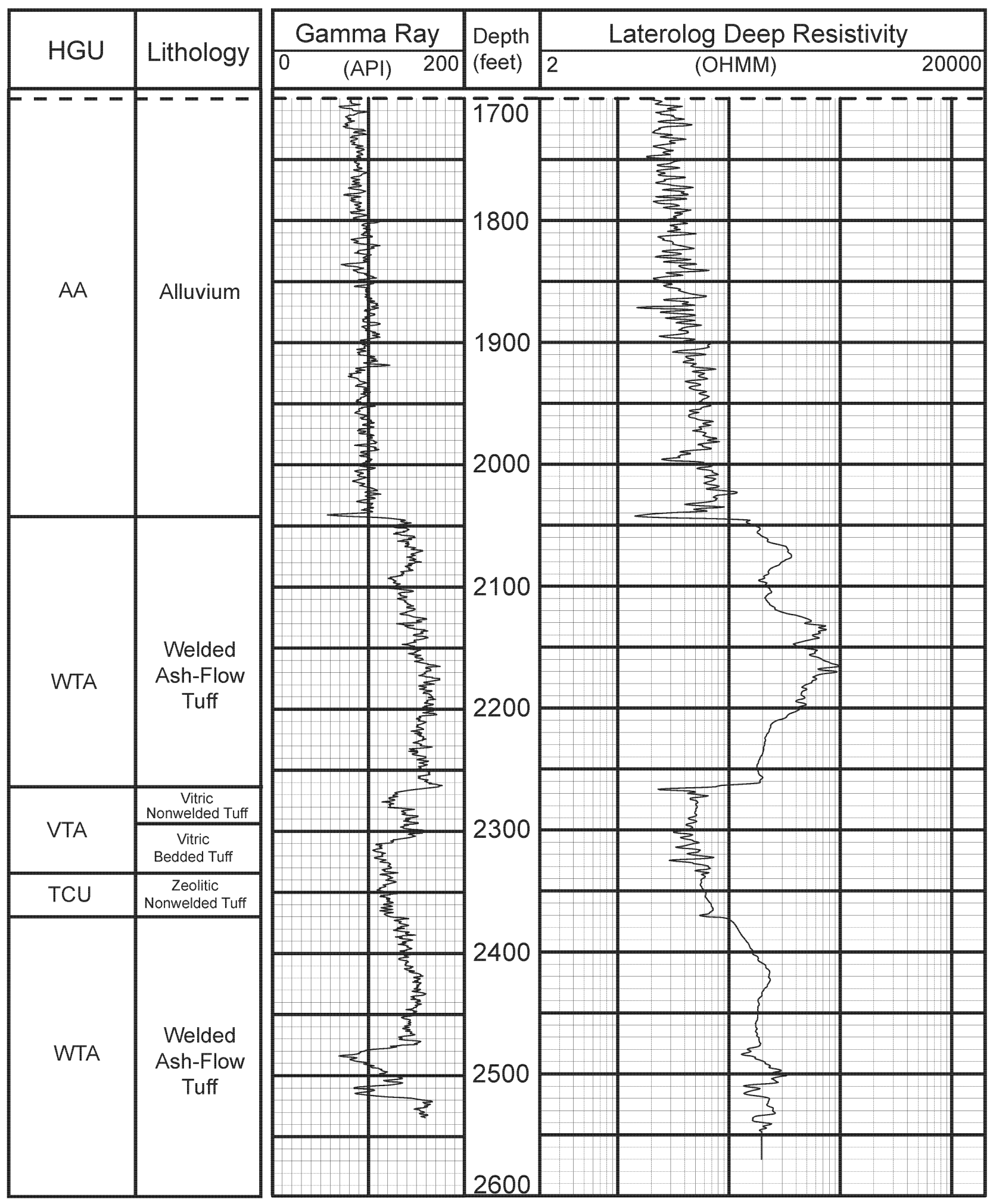

Figure 3-14

Bottom Portions of the Gamma-Ray Log and Laterolog from Well ER-5-3 
Flat Phase 2 data collection activities, provide an excellent opportunity to demonstrate the ability of geophysical logs to add confidence in subsurface interpretations through correlation techniques.

Prior to UGTA Phase 2 drilling in Frenchman Flat, WTAs within the Ammonia Tanks Tuff and Rainier Mesa Tuff of the Timber Mountain Group were known to underlie the northern portion of Frenchman Flat (IT, 1998). Although no previously existing holes in central Frenchman Flat were drilled deep enough to encounter Timber Mountain units, it was thought that the Timber Mountain Group WTAs did not extend southward to the central portion of the basin. However, Well ER-5-4 \#2, located in central Frenchman Flat, encountered WTAs of the Timber Mountain Group, which indicates that the Timber Mountain WTAs do indeed extend into central Frenchman Flat. This is particularly evident when correlating the laterolog from Well ER-5-3, drilled in the northern portion of Frenchman Flat, with the laterolog from Well ER-5-4 \#2 (Figure 3-15). Although the two wells are $6.2 \mathrm{~km}$ (3.9 mi) apart and the difference in the elevation of the Timber Mountain units in the wells is $560 \mathrm{~m}(1,837 \mathrm{ft})$, the resistivity signatures of the Timber Mountain units in both wells are remarkably similar, particularly for the WTA formed by welded ash-flow tuff of the Ammonia Tanks Tuff. Both occurrences are similar in thickness and have the same welding profile characterized by an increase in welding, and associated increase in resistivity, towards the interior portions of the HGUs. The interval of nonwelded ash-flow tuff and bedded tuff that is present between the WTAs of the Ammonia Tanks and Rainier Mesa tuffs also correlates very well between the wells, even though the interval in Well ER-5-3 is mostly vitric while the same interval in Well ER-5-4 \#2 is zeolitic (NNSA/NSO, 2005a; 2005b). The overlying AA in both wells shows the jagged resistivity signature typical of highly bedded units like alluvium. The lower resistivity values in the alluvium in Well ER-5-4 \#2 is due to the presence of zeolitic alteration (Warren et al., 2002). 


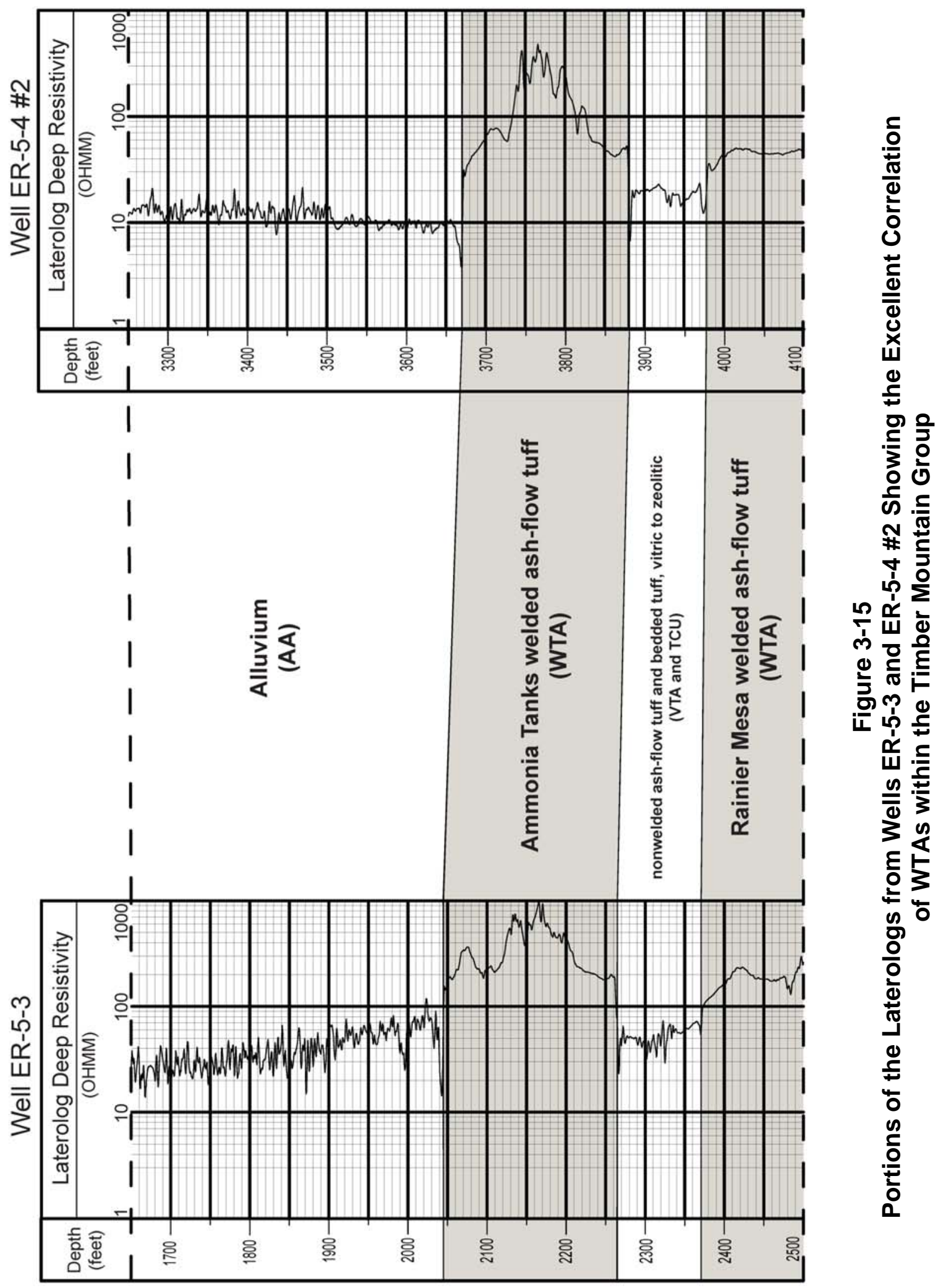


This page intentionally left blank. 


\subsection{Summary}

Geophysical logs have been, and remain, an important part of the arsenal of subsurface interpretation tools available to NTS geoscientists. The UGTA project continues to reap the benefits from the vast amount of geophysical log data and the large knowledge base on interpretation of geophysical logs in NTS rocks acquired during the past 50 years. Geophysical logs provide UGTA scientists with information critical for accurately and confidently identifying, characterizing, and correlating HGUs, which are the basic components of HSUs that form the building blocks of HFMs. Rocks in the NTS area are classified as one of ten HGUs based mainly on the rock's primary lithology, type and degree of post-depositional alteration, and propensity to fracture. Fortunately, these characteristics control or influence various geophysical log measurements and, thus, allow the use of logs to help in the delineation and characterization of NTS HGUs. Geophysical log data from UGTA wells are closely integrated with other borehole data, as well as information from nearby boreholes and surface geologic exposures, to produce comprehensive geologic and hydrogeologic interpretations. 
This page intentionally left blank. 


\subsection{References}

See Appendix A for references related to development of geophysical logging techniques at the Nevada Test Site.

Asquith, G. B., and D. A. Krygowski, 2004. Basic Well Log Analysis. American Association of Petroleum Geologists Methods in Exploration Series, No. 16, Tulsa, OK: American Association of Petroleum Geologists, 244 pp.

Bechtel Nevada, 2005. A Hydrostratigraphic Model and Alternatives for the Groundwater Flow and Contaminant Transport Model of Corrective Action Unit 98: Frenchman Flat, Clark, Lincoln, and Nye County, Nevada. DOE/NV/11718--1064. Las Vegas, NV.

Bechtel Nevada, 2006. A Hydrostratigraphic Model and Alternatives for the Groundwater Flow and Contaminant Transport Model of Corrective Action Unit 97: Yucca Flat-Climax Mine, Lincoln and Nye Counties, Nevada. DOE/NV/11718--1119. Las Vegas, NV.

BN, see Bechtel Nevada.

Byers, F. M., Jr., W. J. Carr, P. P. Orkild, W. D. Quinlivan, and K. A. Sargent, 1976. Volcanic Suites and Related Cauldrons of the Timber Mountain-Oasis Valley Caldera Complex, Southern Nevada. U.S. Geological Survey Professional Paper 919, 70 pp. Washington, D.C.

Gatlin C., 1960. Petroleum Engineering: Drilling and Well Completions. Englewood Cliffs, NJ: Prentice-Hall Inc., 341 pp.

Hilchie, D. W., 1978. Applied Openhole Log Interpretation. Golden, CO: D. W. Hilchie, Inc., 309 pp.

IT Corporation, 1996. Regional Geologic Model Documentation Package (Phase I Data Analysis Documentation, Volume I, Parts 1 and 2). ITLV/10972-181. Prepared for the U.S. Department of Energy, Nevada Operations Office. Las Vegas, NV.

IT Corporation, 1998. Underground Test Area Subproject, Corrective Action Unit 98: Frenchman Flat Data Analysis Task, Volume I-Hydrostratigraphic Model Documentation Package, Draft. ITLV/13052-044. Las Vegas, NV.

IT, see IT Corporation.

Laczniak, R. J., J. C. Cole, D. A. Sawyer, and D. A. Trudeau, 1996. Summary of Hydrogeologic Controls on the Movement of Groundwater at the Nevada Test Site, Nye County, Nevada. U.S. Geological Survey, Water-Resources Investigations Report 96-4109, 59 pp. Carson City, NV. 
Merkel, R. H., 1983. Well Log Formation Evaluation. American Association of Petroleum Geologists Continuing Education Course Note Series \#14. Tulsa, OK: American Association of Petroleum Geologists, 82 pp.

National Security Technologies, LLC, 2007. A Hydrostratigraphic Model and Alternatives for the Groundwater Flow and Contaminant Transport Model of Corrective Action Unit 99: Rainier Mesa-Shoshone Mountain, Nye Counties, Nevada. DOE/NV/25946--146. Las Vegas, NV.

NNSA/NSO, see U.S. Department of Energy, National Nuclear Security Administration Nevada Site Office.

NSTec, see National Security Technologies, LLC.

Prothro, L. B. S. L. Drellack, Jr., and J. M. Mercadante, 2009. A Hydrostratigraphic System for Modeling Groundwater Flow and Radionuclide Migration at the Corrective Action Unit Scale, Nevada Test Site and Surrounding Areas, Clark, Lincoln, and Nye Counties, Nevada. DOE/NV/25946--630. National Security Technologies, LLC, Las Vegas, NV.

Sawyer, D. A., R. J. Fleck, M. A. Lamphere, R. G. Warren, and D. E. Broxton, 1994. "Episodic Caldera Volcanism in the Miocene Southwest Nevada Volcanic Field: Revised Stratigraphic Caldera Framework, 40Ar/39Ar Geochronology and Implications for Magmatism and Extension.” Geological Society of America Bulletin, vol. 67, no. 10, pp. 1,304-1,318.

Slate, J. L., M. E. Berry, P. D. Rowley, C. J. Fridrich, K. S. Morgan, J. B. Workman, O. D. Young, G. L. Dixon, V. S. Williams, E. H. McKee, D. A. Ponce, T. G. Hildenbrand, WC Swadley, S. C. Lundstrom, E. B. Ekren, R. G. Warren, J. C. Cole, R. J. Fleck, M. A. Lanphere, D. A. Sawyer, S. A. Minor, D. J. Grunwald, R. J. Laczniak, C. M. Menges, J. C. Yount, and A. S. Jayko, 1999. Digital Geologic Map of the Nevada Test Site and Vicinity, Nye, Lincoln, and Clark Counties, Nevada and Inyo County, California. U.S. Geological Survey Open-File Report 99-554-A, scale 1:120,000.

U.S. Department of Energy, Nevada Operations Office, 2000. Completion Report for Well ER-EC-1. DOE/NV/11718--381. Prepared by Bechtel Nevada, Las Vegas, NV.

U.S. Department of Energy, National Nuclear Security Administration Nevada Site Office, 2004a. Completion Report for Well ER-2-1. DOE/NV/11718--893. Prepared by Bechtel Nevada, Las Vegas, NV.

U.S. Department of Energy, National Nuclear Security Administration Nevada Site Office, 2004b. Completion Report for Well ER-12-2. DOE/NV/11718--846. Prepared by Bechtel Nevada, Las Vegas, NV.

U.S. Department of Energy, National Nuclear Security Administration Nevada Site Office, 2005a. Well Completion Report for Well Cluster ER-5-4. DOE/NV/11718--998. Prepared by Bechtel Nevada, Las Vegas, NV. 
U.S. Department of Energy, National Nuclear Security Administration Nevada Site Office, 2005b. Well Completion Report for Well Cluster ER-5-3. DOE/NV/11718--1093. Prepared by Bechtel Nevada, Las Vegas, NV.

U.S. Department of Energy, National Nuclear Security Administration Nevada Site Office, 2006. Completion Report for Well ER-12-3. DOE/NV/11718--1182. Prepared by Bechtel Nevada, Las Vegas, NV.

Warren, R. G., F. C. Benedict Jr., T. P. Rose, D. K. Smith, S. J. Chipera, E. C. Kluk, and K. M. Raven, 2002. Alluvial Layering and Distribution of Reactive Phases within Drill Holes ER-5-4 and UE-5n of Frenchman Flat. Los Alamos National Laboratory Report LA-UR-02-6206. Los Alamos, NM.

Winograd, I. J., and W. Thordarson, 1975. Hydrogeologic and Hydrochemical Framework, South-Central Great Basin, Nevada-California, with Special Reference to the Nevada Test Site. U.S. Geological Survey Professional Paper 712-C, 126 pp. 
This page intentionally left blank. 


\section{Distribution List}

\section{$\underline{\text { Copies }}$}

W. R. Wilborn

U.S. Department of Energy

1 paper/1 CD

National Nuclear Security Administration

Nevada Site Office

Environmental Restoration Division

P.O. Box 98518, M/S 505

Las Vegas, NV 89193-8518

U.S. Department of Energy

National Nuclear Security Administration

Nevada Site Office

Technical Library

P.O. Box 98518, M/S 505

Las Vegas, NV 89193-8518

U.S. Department of Energy

National Nuclear Security Administration

Nevada Site Office

Public Reading Facility

c/o Nuclear Testing Archive

P.O. Box 98521, M/S 400

Las Vegas, NV 89193-8521

U.S. Department of Energy

Office of Scientific and Technical Information

$1 \mathrm{CD}$ (uncontrolled)

P.O. Box 62

Oak Ridge, TN 378831-0061

N. M. Becker

Los Alamos National Laboratory

P.O. Box 1663, EES-6, M/S T-003

Los Alamos, NM 87545-1663

B. M. Crowe

Environmental Restoration Project

2 CDs (uncontrolled)

U.S. Department of Energy

National Nuclear Security Administration

Nevada Site Office

P.O. Box 98518, M/S 505

Las Vegas, NV 89193-8518

E. M. Kwicklis

Los Alamos National Laboratory

1 electronic copy (uncontrolled)

P. O. Box 1663

Los Alamos, NM 87545-1663

1 paper/1 CD

1 paper/1 CD

Dist-1 


\section{Distribution List}

$\underline{\text { Copies }}$

S. Marutzky

1 paper/1CD

Stoller-Navarro Joint Venture

232 Energy Way, M/S 439

Las Vegas, NV 89129

P. K. Ortego

National Security Technologies, LLC

1 paper/1 CD

P.O. Box 98521, NLV082

Las Vegas, NV 89193-8521

G. A. Pawloski

1 paper/ $1 C D$

Lawrence Livermore National Laboratory

P.O. Box 808

Livermore, CA 94551-0808

G. Ruskauff

$1 \mathrm{CD}$

Stoller-Navarro Joint Venture

232 Energy Way, MS 439

North Las Vegas, NV 89030

C. E. Russell

Desert Research Institute

755 East Flamingo Road

P.O. Box 19040

Las Vegas, NV 89119-7363

Stoller-Navarro Library

Stoller-Navarro Joint Venture

232 Energy Way, M/S 439

North Las Vegas, NV 89030

B. K. Thompson

Water Resources, Nevada District

U.S. Geological Survey

160 N. Stephanie Street

Henderson, NV 89074

A. V. Wolfsberg Los Alamos National Laboratory

P. O. Box 1663, EES-6, M/S T003

Los Alamos, NM 87545-1663

M. Zavarin

1 paper/1 CD

Lawrence Livermore National Laboratory

P. O. Box 808

Livermore, CA 94551-0808 


\section{APPENDIX A}

List of References Related to the Development of Geophysical Logging Techniques at the Nevada Test Site 



\section{References Related to the Development of Geophysical Logging Techniques at the Nevada Test Site}

Axelrod, M. C., and J. R. Hearst, 1981. “Calibration of a Neutron Log in Partially Saturated Media Part III: A Comparison of Logs and Sidewall Samples.” In: Jones, E., ed., Monterey Containment Symposium, Lawrence Livermore National Laboratory, p. 16.

Batra, R., 1983. “A Possible New Acoustic Logging Probe for NTS.” In: Olsen, C., ed., The Second Symposium on Containment of Underground Nuclear Explosions, Lawrence Livermore National Laboratory. CONF-830882, vol. 1, p. 103.

Burkhard, N. R., 1987. “Applications of Vertical Seismic Profiling at NTS.” In: Olsen, C., and S. Warner, eds., The Fourth Symposium on Containment of Underground Nuclear Explosions, Sandia National Laboratory. CONF-870961, vol. 2, p. 77.

Burkhard, N. R., and J. R. Hearst, 1989. "Bound Water Corrections to Epithermal-NeutronDerived Water Contents.” In: Olsen, C., and S. Warner, eds., The Fifth Symposium on the Containment of Underground Nuclear Explosions, Lawrence Livermore National Laboratory. CONF-8909163, vol. 2, p. 206.

Burkhard, N. R., 1993. “An In Situ Check of the Epithermal Neutron Log Calibration.” In: Olsen, C., ed., The Seventh Symposium on Containment of Underground Nuclear Explosions, Lawrence Livermore National Laboratory. CONF-9309103, vol. 2, p. 413.

Carroll, R. D., 1989. Density Logging and Density of Rocks in Rainier Mesa Area, Nevada Test Site. U.S. Geological Survey Open-File Report OFR-89-329, 72 pp. Denver, CO.

Carroll, R. D., 1990. Electric Logging and Electrical Properties of Rocks in the Rainier Mesa Area, Nevada Test Site. U.S. Geological Survey Open-File Report OFR-90-31, 90 pp. Denver, CO.

Carroll, R. D., and J. E. Magner, 1988. Velocity Logging and Seismic Velocity of Rocks in the Rainier Mesa Area, Nevada Test Site, Nevada. U.S. Geological Survey Open-File Report OFR-88-380, 85 pp. Denver, CO.

Carlson, R. C., 1993. "Maximum Likelihood Borehole Corrections for Dual-Detector Density Logs.” In: Olsen, C., ed., The Seventh Symposium on Containment of Underground Nuclear Explosions, Lawrence Livermore National Laboratory. CONF-9309103, vol. 2, p. 407.

Clark, S. R., 1985. “Oriented Logging Tools at the Nevada Test Site.” In: Olsen, C., ed., The Third Symposium on Containment of Underground Nuclear Explosions, Lawrence Livermore National Laboratory. CONF-850953, vol. 2, p. 314. 
Conaway, J. G., 1987. “Temperature Logging as an Aid to Understanding Groundwater Flow in NTS Boreholes.” In: Olsen, C., and S. Warner, eds., The Fourth Symposium on Containment of Underground Nuclear Explosions, Sandia National Laboratories. CONF-870961, vol. 2, p. 373.

Conaway, J. G., 1989. "Distortion of Geophysical Logs Near Bed Boundaries and in Complex Lithologies.” In: Olsen, C., and S. Warner, eds., The Fifth Symposium on the Containment of Underground Nuclear Explosions, Lawrence Livermore National Laboratory. CONF-8909163, vol. 2, p. 337.

Drellack, S. L., Jr., 1994. Written communication: An Introduction to NTS Geology and Geophysical Log Characteristics, Raytheon Services Nevada Technical Report, 70 pp. Las Vegas, NV.

Gradie, J. C., and T. L. Roush, 1987. "Spectral Reflectance Characteristics of Clay-Bearing Soils: Applications to Downhole Environments.” In: Olsen, C., and S. Warner, eds., The Fourth Symposium on Containment of Underground Nuclear Explosions, Sandia National Laboratories. CONF-870961, vol. 2, p. 201.

Hawkins, W. L., R. D. Oliver, and M. J. Lavelle, 1987. “Borehole Inspection System for Large Diameter Holes.” In: Olsen, C., and S. Warner, eds., The Fourth Symposium on Containment of Underground Nuclear Explosions, Sandia National Laboratories. CONF-870961, vol. 2, p. 18.

Hearst, J. R., and N. R. Burkhard, 1989. “A Study of the Difference Between Gravimetric and Gamma-Gamma Density Near the Surface in Northern Yucca Flat.” In: Olsen, C., and S. Warner, eds., The Fifth Symposium on the Containment of Underground Nuclear Explosions, Lawrence Livermore National Laboratory. CONF-8909163, vol. 2, p. 310.

Hearst, J. R., and R. C. Carlson, 1993. “A Comparison of the Moisture Gauge and the Neutron Log in Air-Filled Holes at NTS.” In: Olsen, C., ed., The Seventh Symposium on Containment of Underground Nuclear Explosions, Lawrence Livermore National Laboratory. CONF-9309103, vol. 2, p. 399.

Hearst, J. R., J. G. Conaway, M. A. Mathews, and J. W. Barber, 1989. "In-Situ Equivalent CO2 Estimates Using a Neutron-Induced Gamma-Ray Spectroscopy Logging System.” In: Olsen, C., and S. Warner, eds., The Fifth Symposium on the Containment of Underground Nuclear Explosions, Lawrence Livermore National Laboratory. CONF-8909163, vol. 2, p. 160.

Hearst, J. R, J. G. Conaway, D. E. Treka, and J. A. Grau, 1991. “A Comparison of EnergyWindow and Spectral-Fitting Methods for the Estimation of Carbonate Content in Rocks Using Neutron-Induced Gamma Rays.” In: Olsen, C., and M. Price, eds., The Sixth Symposium on the Containment of Underground Nuclear Explosions, Lawrence Livermore National Laboratory. CONF-9109114, vol. 1, p. 16. 
Long-ji, H., and J. R. Hearst, 1983. “Spectral Gamma-Ray Logging for Clay Content.” In:

Olsen, C., ed., The Second Symposium on Containment of Underground Nuclear Explosions, Lawrence Livermore National Laboratory. CONF-830882, vol. 1, p. 113.

Marusak, N. L., 1981. “Stratigraphic Interpretation Using Electric Logs.” In: Jones, E., ed., Monterey Containment Symposium, Lawrence Livermore National Laboratory, p. 18.

Mathews, M. A., and C. M. LaDelfe, 1983. "Lithology and Log Comparison of Some Boreholes in Southern Yucca Flat.” In: Olsen, C., ed., The Second Symposium on Containment of Underground Nuclear Explosions, Lawrence Livermore National Laboratory. CONF-830882, vol. 1, p. 121.

Mathews, M. A., and K. A. Fenster, 1991. "Formation Elastic Parameters from Acoustic and Density Logs in Emplacement Holes.” In: Olsen, C., and M. Price, eds., The Sixth Symposium on the Containment of Underground Nuclear Explosions, Lawrence Livermore National Laboratory. CONF-9109114, vol. 1, p. 60.

Mathews, M. A., R. C. Warren, S. R. Garcia, and M. J. Lavelle, 1985. “A Preliminary Report on NTS Spectral Gamma Logging and Calibration Models.” In: Olsen, C., ed., The Third Symposium on Containment of Underground Nuclear Explosions, Lawrence Livermore National Laboratory. CONF-850953, vol. 2, p. 299.

Mathews, M. A., R. G. Warren, and K. A. Taylor, 1985. "Investigation of Magnetic Susceptibility Logs Acquired in Satellite Holes in Areas 7 and 19.” In: Olsen, C., ed., The Third Symposium on Containment of Underground Nuclear Explosions, Lawrence Livermore National Laboratory. CONF-850953, vol. 2, p. 99.

McKague, H. L., K. L. Ward, and J. R. Hearst, 1991. “Nuclear Magnetic Resonance Determination of the Non-Pore Water Content of Zeolitic Tuffs and its Application to Correction of Epithermal-Neutron Log-Derived Water Content.” In: Olsen, C., and M. Price, eds., The Sixth Symposium on the Containment of Underground Nuclear Explosions, Lawrence Livermore National Laboratory. CONF-9109114, vol. 1, p. 3.

Newmark, R. L., 1987. "Shear Wave Velocities from Sonic Logs In Emplacement Holes.” In: Olsen, C., and S. Warner, eds., The Fourth Symposium on Containment of Underground Nuclear Explosions, Sandia National Laboratories. CONF-870961, vol. 2, p. 89.

Oliver, R. D., 1983. “Containment Well Logging Program.” In: Olsen, C., ed., The Second Symposium on Containment of Underground Nuclear Explosions, Lawrence Livermore National Laboratory. CONF-830882, vol. 1, p. 97.

Pawloski, G. A., 1981. “Resistivity Measurements as an Indication of Clay Content.” In: Jones, E., ed., Monterey Containment Symposium, Lawrence Livermore National Laboratory, p. 15. 
Pawloski, G. A., H. L. McKague, J. L. Wagoner, and W. B. McKinnis, 1991. “A Preliminary Guidebook for Identifying Stratigraphic Contacts at the Nevada Test Site.” In: Olsen, C., and M. Price, eds., The Sixth Symposium on the Containment of Underground Nuclear Explosions, Lawrence Livermore National Laboratory. CONF-9109114, vol. 2, p. 265.

Rambo, J. T., and R. P. Swift, 1987. “A Possible Relation Between Sonic Velocity Measured at the Edge of a Large Borehole and Shear Failure.” In: Olsen, C., and S. Warner, eds., The Fourth Symposium on Containment of Underground Nuclear Explosions, Sandia National Laboratories. CONF-870961, vol. 2, p. 135.

Schock, R. N., 1981. “Correlation Between Rock Strength and Acoustic Wave Velocity.” In: Jones, E., ed., Monterey Containment Symposium, Lawrence Livermore National Laboratory, p. 13.

Sweeney, J., and P. Harben, 1985. “Evaluation of the Utility of a Large-Spacing Dipole-Dipole Borehole Logging Tool.” In: Olsen, C., ed., The Third Symposium on Containment of Underground Nuclear Explosions, Lawrence Livermore National Laboratory. CONF-850953, vol. 2, p. 355.

Wagoner, J. L., 1981. "Use of Gamma Logs to Correlate Alluvium in Northern Yucca Flat, NTS.” In: Jones, E., ed., Monterey Containment Symposium, Lawrence Livermore National Laboratory, p. 19. 